\title{
A revision of the akysid catfish genus Acrochordonichthys Bleeker
}

\author{
H. H. $\mathrm{NG}^{* \dagger \dagger}$ AND P. K. L. $\mathrm{NG}^{\dagger}$ \\ *Fish Division, Museum of Zoology, University of Michigan, 1109 Geddes Avenue, \\ Ann Arbor, Michigan 48109-1079, U.S.A. and †Department of Biological Sciences, \\ National University of Singapore, 10 Kent Ridge Crescent, Singapore 119260
}

(Received 6 May 2000, Accepted 5 September 2000)

\begin{abstract}
The taxonomy of the South-east Asian catfish genus Acrochordonichthys (Akysidae) is revised. The shapes of the snout, humeral process and adipose fins are diagnostic species characters. Only four out of 11 species and one sub-species described prior to this study are considered valid, namely $A$. rugosus (Bleeker, 1847), A. ischnosoma Bleeker, 1858, A. chamaeleon (Vaillant, 1902), and A. pachyderma Vaillant, 1902. An additional five new species (A. guttatus, A. septentrionalis, A. mahakamensis, A. strigosus and A. falcifer) are described.
\end{abstract}

(C) 2001 The Fisheries Society of the British Isles

Key words: Akysidae; Acrochordonichthys; South-east Asia; taxonomy.

\section{INTRODUCTION}

The South-east Asian catfish family Akysidae includes nearly 40 nominal species in four genera (Acrochordonichthys, Akysis, Breitensteinia, Parakysis), most of which are generally found in deeper parts of relatively swift rivers and forest streams. The genus Acrochordonichthys Bleeker, 1858, is characterized by a highly rugose skin with tubercles arranged in longitudinal rows along the side of the body, presence of a long, low adipose fin, and truncate caudal fin. Eleven nominal species and one nominal subspecies of Acrochordonichthys are known (Roberts, 1989).

During the past few years, the authors and their colleagues have been revising gradually the taxonomy of the family Akysidae ( $\mathrm{Ng} \& \mathrm{Lim}, 1995$; $\mathrm{Ng} \&$ Kottelat, 1998; Ng \& Siebert, 1998) and as part of this project, a revision of the genus Acrochordonichthys is presented here.

\section{MATERIALS AND METHODS}

The species concept used is the phylogenetic species concept, which considers a species to be a single lineage of an ancestor-descendant population that maintains its identity from other such lineages and has its own evolutionary tendencies and historical fate (Wiley, 1981). Because of the paucity of the material available, a detailed phylogenetic study is not possible and relationships have been inferred based on the fact that the species are recognizably different

\$Author to whom correspondence should be addressed. Tel.: +1 734647 2192; fax: +1 734763 4080; email: heokheen@umich.edu 
and can be diagnosed by a unique set of characters exhibited by all members of the species. In this respect, this is closer to the pragmatic species concept of Kottelat (1995), but as pointed out by Cracraft (1989), the results can be very close.

Measurements were made with dial callipers and recorded to $0 \cdot 1 \mathrm{~mm}$. Counts and measurements were made on the left side of a specimen whenever possible and follow Ng \& Kottelat (1998) throughout with the following additions: head depth is measured at the base of the occipital process, occipital process length is measured from the base to the tip, and occipital process width is measured at the base of the occipital process. All measurements of body parts are given as proportions of standard length $\left(L_{\mathrm{S}}\right)$ and head length $\left(L_{\mathrm{H}}\right)$.

Fin-ray counts were obtained under transmitted light using a binocular dissecting microscope; the terminology of Hubbs \& Lagler (1947) is used. Gill raker counts were reported using the method and terminology of Roberts (1992). Vertebral counts were taken from radiographs using the method and terminology of Roberts (1994). Numbers in parentheses following particular fin-ray, vertebral, branchiostegal-ray or gill-raker count are the numbers of specimens examined.

Drawings were made with a Nikon SMZ-10 microscopic camera lucida. Institutional codes for the repositories of specimens follow Eschmeyer (1998), with the following additions: collection of the Fisheries Department of Sarawak, Kuching (FDS) and Sabah Museum, Kota Kinabalu (SSM).

\section{RESULTS}

ACROCHORDONICHTHYS BLEEKER, 1858

Acrochordonichthys Bleeker, 1858 (type species Acrochordonichthys platycephalus Bleeker, 1858, by subsequent designation in Bleeker, 1862: 13). Gender: masculine.

Sosia Vaillant, 1902 (type species Sosia chamaeleon Vaillant, 1902, by monotypy). Gender: feminine.

\section{Differential diagnosis}

A genus of akysid catfishes characterized by highly rugose skin with tubercles arranged in longitudinal rows along the side of the body, a long, low adipose fin (absent in Breitensteinia), and weakly emarginate caudal fin and in possessing the following series of synapomorphies (de Pinna, 1996), which are shared with Breitensteinia: proximal end of anterior ceratohyal with narrow anterior extension directed anterolaterally, mesethmoid cornua with dorsal sub-division and paired fontanels between supraoccipital, frontals and sphenotics.

\section{Remarks}

Identification of Acrochordonichthys species has been difficult because of morphological similarity. Roberts (1989) believed that failure to recognize variation in colouration, sexual dimorphism, development of epidermal structures and the occipital process was the primary cause of the present taxonomic confusion. Many samples of Acrochordonichthys have been represented by a single specimen, exacerbating the problem (Roberts, 1989). 
Based on external morphology, two groups of species can be distinguished easily, both of which may be artificial. However, the recognition of groups will aid in the discussion of the complicated taxonomy of the various species. The first group consists of species with a more slender caudal peduncle (depth of caudal peduncle $4 \cdot 7-5 \cdot 3 \% L_{\mathrm{S}}$ ), narrower head (head width $18 \cdot 3-21 \cdot 9 \% L_{\mathrm{S}}$ ), and 39-41 vertebrae. Acrochordonichthys ischnosoma is the only species described in this group: the present paper describes four more species, namely A. guttatus, A. mahakamensis, A. septentrionalis and A. strigosus. The second group consists of species with a deeper caudal peduncle (depth of caudal peduncle $5 \cdot 5-8 \cdot 8 \% L_{\mathrm{S}}$ ), broader head (head width $22 \cdot 0-29 \cdot 6 \% L_{\mathrm{S}}$ ), and 35-37 vertebrae. The other 10 nominal species and one nominal sub-species described previously, namely A. buettikoferi, Sosia chamaeleon, S. chamaeleon var. pallida, A. melanogaster, A. obscurus, A. pachyderma, A. platycephalus, A. pleurostigma, A. rugosus, $A$. varius, and $A$. zonatus, belong to this group. One more species, $A$. falcifer, is described in this paper. For the purposes of convenient discussion, the species will be compared with congeners in their respective species groups only.

Sexual dimorphism has been reported in Akysis by $\mathrm{Ng}$ \& Kottelat (1996, 1998), Breitensteinia by $\mathrm{Ng} \&$ Siebert (1998), and Acrochordonichthys by $\mathrm{Ng} \&$ Rachmatika (1999). Males have the anus situated immediately in front of a genital papilla, which is located posterior to the pelvic fin base. The genital opening is situated at the tip of the papilla, covered by a fleshy flap. In females, the anus is situated more posteriorly and the genital opening is located at the tip of a short genital appendage. Male specimens of $A$. chamaeleon and $A$. strigosus dissected possessed testes with elongate digitiform lateral processes similar to those reported in Breitensteinia by Roberts (1989), while a single female A. chamaeleon dissected had numerous ripe ova of $c .0 .8 \mathrm{~mm}$ in diameter.

The biology of Acrochordonichthys is unusual and would make a fascinating subject for study. The axillary pore (or porus pectoralis) lying just below the humeral process in Acrochordonichthys is unusually large, and produces a milky-white mucus-like secretion when the fish is severely disturbed (pers. obs.). The exact function of this secretion is unknown, but it has ichthyocidal properties: a large specimen of $c .90 \mathrm{~mm} L_{\mathrm{S}}$ was placed in a tank with a few other fishes, and upon production of the mucus, all the other fishes in the tank died within the space of a few minutes (pers. obs.). This secretion may therefore be defensive in nature.

A total of 55 specimens of A. rugosus from five different drainages in the Malay Peninsula, namely the Bernam, Pahang, Perak, Terengganu and Mae Nam Sungai Kolok rivers were examined for intraspecific variation in colouration, morphology, and the development of epidermal structures, the results of which are presented below.

Head width: The shape of the head, which is partly due to its width, has been used to differentiate various akysid species, e.g. by Kottelat et al. (1993) for Acrochordonichthys, $\mathrm{Ng}$ (1996) and Ng \& Kottelat (1996) for Akysis, and by Ng $\&$ Lim (1995) for Parakysis. The head width of Acrochordonichthys is positively allometric with size (and presumably age) $(r=0.675, P<0.001, n=52)$. The differences in head shape between juveniles and adults are substantial enough to have suggested they are separate species, especially if specimens of intermediate sizes are not available for study (Fig. 1). This difference in head width is not 
(a)

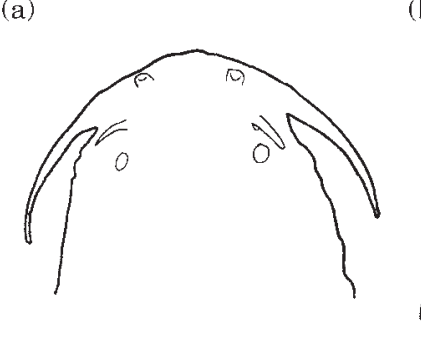

(b)

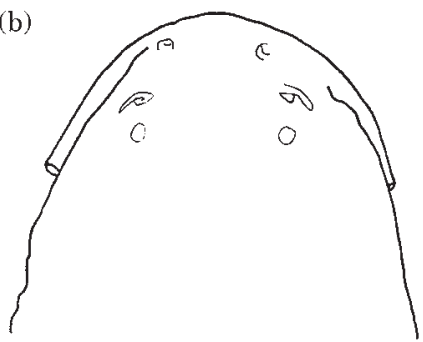

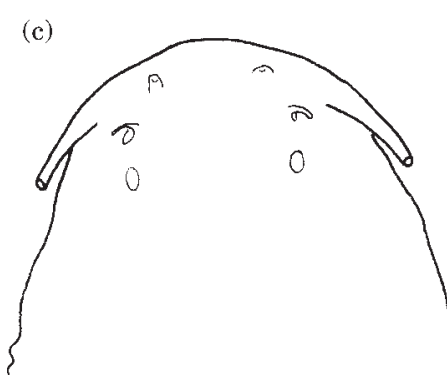

(d)

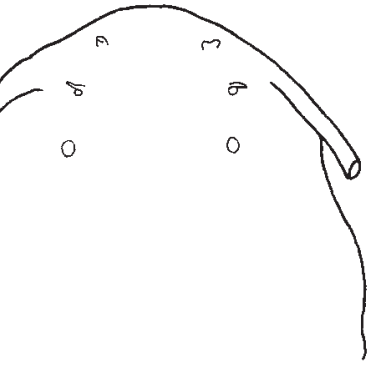

FIG. 1. Dorsal view of heads of Acrochordonichthys rugosus, showing ontogenetic change in head shape: (a) ZRC 38443, 44.5 mm $L_{\mathrm{S}}$; (b) ZRC 5182, 63.5 $\mathrm{mm} L_{\mathrm{S}}$; (c) ZRC 5187, $84.5 \mathrm{~mm} L_{\mathrm{S}}$; (d) ZRC $24517,111 \cdot 0 \mathrm{~mm} L_{\mathrm{S}}$.

sex-related: both sexes show the same trend as they increase in size. Even though there may be considerable changes in head width during growth, the shape of the snout does not change significantly and is useful as a diagnostic character.

Body depth: The depth of the body at the anus for Acrochordonichthys increases with age $(r=0.673, P<0.001, n=52)$ and is not sex-related.

Colouration (Fig. 2): The colouration is extremely variable, even among specimens from the same locality. Most have a light-brown saddle extending for the length of the adipose fin and some have spots on the side of the body in place of the saddle. Eleven out of 55 had a reversed colour pattern, with the body a predominantly light brown with a few dark brown patches $v$. dark brown body with light-brown patches. This variation could be due to skin moulting (see below). In the closely related Breitensteinia, skin moulting is accompanied by a temporary loss in pigmentation: the underlying skin is devoid of pigmentation and the fish is a very pale pink (pers. obs.). This condition is likely to exist in Acrochordonichthys as well.

Even though the colouration is highly variable, some general patterns are evident: no individual $A$. rugosus had distinctive small blotches of various shades of brown (as seen in A. falcifer). Therefore, colour is a useful diagnostic character when variation is taken into account.

Occipital process: The length of the occipital process relative to its width has been used as a diagnostic character separating the species by various authors (Bleeker, 1858; Weber \& de Beaufort, 1913, Hora \& Gupta, 1941). The present study showed that this ratio cannot be used as a diagnostic character, because of much intraspecific variation. Among 55 A rugosus, the ratio ranged from $2 \cdot 27$ to $4 \cdot 25$, with no apparent ontogenetic pattern. 

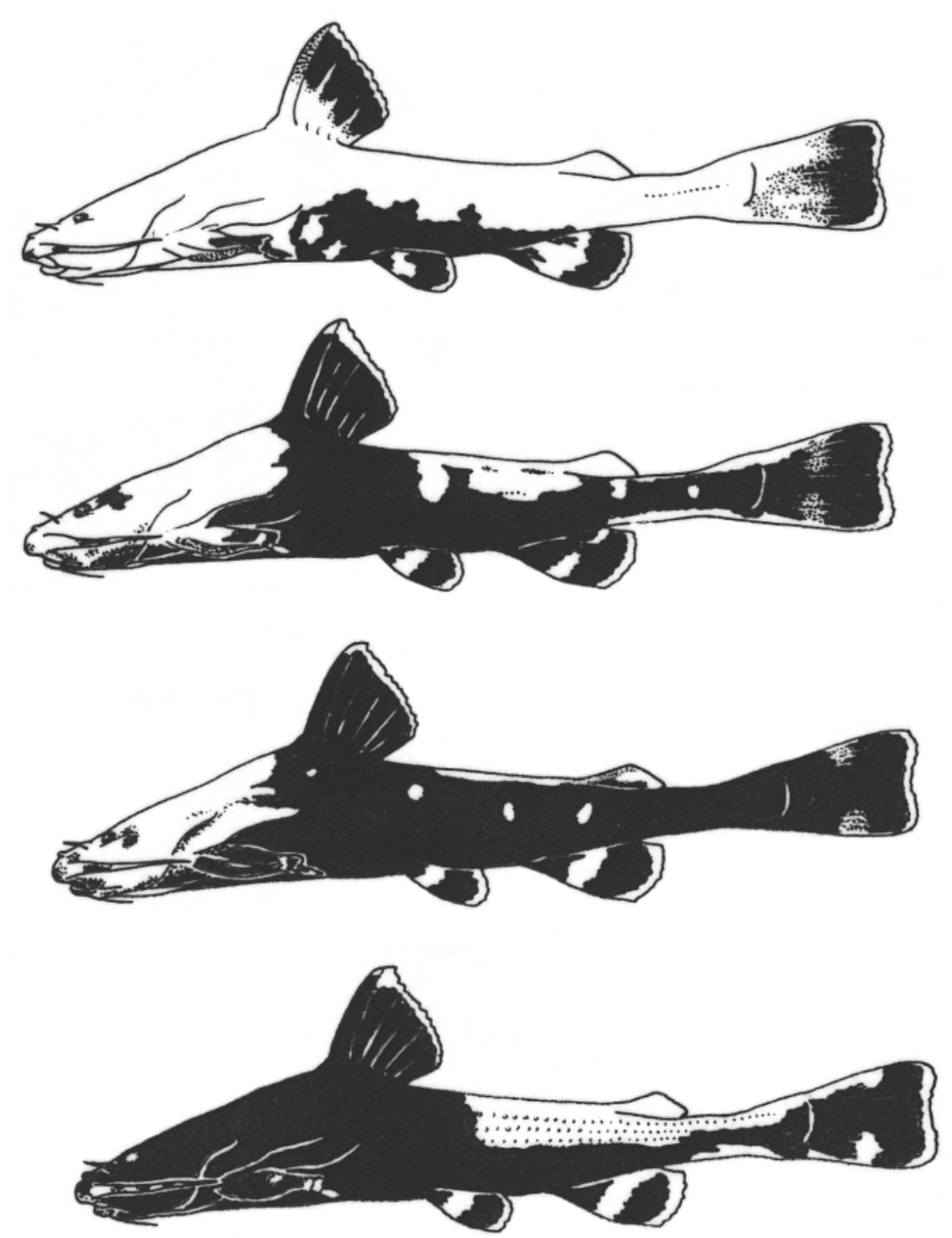

FIG. 2. Schematic illustration showing variation in the colour of Acrochordonichthys rugosus.

Fontanels: Bleeker (1858) used the shape, number and disposition of fontanels to distinguish species of Acrochordonichthys, based on the extent of the median cranial fontanel, the presence or absence of the fonticuli laterales and whether they were positioned in the middle or the posterior part of the neurocranium. Presumably, the fonticuli laterales in the middle referred to the paired fontanels among the supraoccipital, frontals and sphenotics and those at the posterior to the supratemporal fossae. This scheme was largely adhered to by Weber \& de Beaufort (1913), although they considered all of Vaillant's (1902) and Popta's (1904) species to be conspecific with $A$. melanogaster ' . . though their median fontanel is far distant from the base of the occipital process, at the base of which 


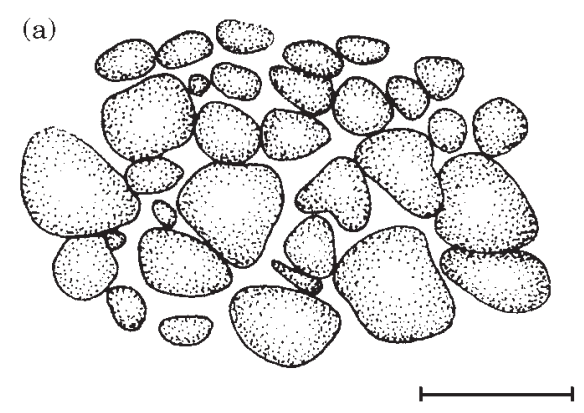

(b)

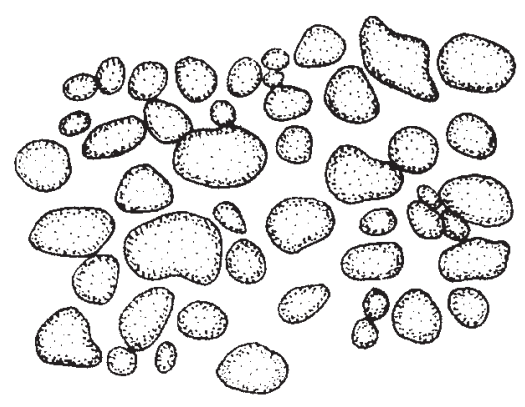

FIG. 3. Close-up view of tubercles of Acrochordonichthys rugosus seen dorsally: (a) better developed (more rounded and tightly packed; ZRC 5167, 46.2 $\mathrm{mm} L_{\mathrm{S}}$ ); (b) less developed (more squamous and situated further apart; ZRC 24514, $56 \cdot 1 \mathrm{~mm} L_{\mathrm{S}}$ ). Scale bar $1 \mathrm{~mm}$.

lies a separate small hollow. It may be that Bleeker has overlooked the fact that these fontanels are separated' (Weber \& de Beaufort, 1913: 370).

Examination of many specimens showed that both the median and the paired fontanels are present consistently in the same positions in all Acrochordonichthys species, as are the supratemporal fossae. The size of the fontanels and supratemporal fossae increase with age, with most of the smaller specimens having poorly-developed fontanels. Thus the presence of fontanels and supratemporal fossae is useful in distinguishing Acrochordonichthys from other akysid genera (de Pinna, 1996), but cannot be used to separate the different Acrochordonichthys species.

Epidermal structures: Skin moulting within the Akysidae was hypothesized first by Roberts (1989) for Acrochordonichthys and reported by Ferraris (1991) for Breitensteinia. Examination of preserved and live specimens confirms Roberts' (1989) hypothesis that the tubercles on Acrochordonichthys may become either greatly hypertrophied or greatly reduced at different stages of the moulting cycle. When they are most developed, the tubercles appear more rounded and tightly packed [Fig. 3(a)], but are more squamous (flattened) and further apart [Fig. 3(b)] when least developed. The shape and distribution of tubercles have been used as diagnostic characters in differentiating the species (Vaillant, 1902), but due to their variation within individuals, this character cannot be used reliably.

Given the allometric changes in head width and body depth at anus, these characters can still be used diagnostically when comparing specimens of similar 
sizes. Other characters useful for distinguishing were the shapes of the adipose fins and the humeral processes.

\section{KEY TO THE SPECIES OF ACROCHORDONICHTHYS}

1a Caudal peduncle slender (depth of caudal peduncle $4 \cdot 7-5 \cdot 3 \% L_{\mathrm{S}}$ ); head narrow (head width $\left.18 \cdot 3-21.9 \% L_{\mathrm{S}}\right)$; vertebrae $39-41$. . . . . . . . . 2

1 b Caudal peduncle deep (depth of caudal peduncle $5 \cdot 5-8 \cdot 8 \% L_{\mathrm{S}}$ ); head broad (head width $22 \cdot 0-29 \cdot 6 \% L_{\mathrm{S}}$ ); vertebrae $35-37$. . . . . . . . . . . . 6

2a Dorsal to adipose distance $4 \cdot 4-5 \cdot 7 \% L_{\mathrm{S}}$; branchiostegal rays 4 ; body with few small dark brown spots . . . . . . . . . . . . A. septentrionalis

2b Dorsal to adipose distance $6 \cdot 2-9 \cdot 8 \% L_{S}$; branchiostegal rays 5-6; body with numerous small dark brown spots . . . . . . . . . . . . . . . . . . 3

3a Body depth at anus 10.9-12.8\% $L_{\mathrm{S}}$; humeral process relatively slender (maximum width of humeral process $10 \cdot 0-11 \cdot 8 \%$ its length). .A. guttatus

3 b Body depth at anus $9 \cdot 4-10 \cdot 0 \% \quad L_{S}$; humeral process relatively thick (maximum width of humeral process $13 \cdot 2-18 \cdot 4 \%$ its length) . . . . . . .4

4a Anterior margin of anal fin rounded . . . . . . . . A. mahakamensis

4b Anterior margin of anal fin angular . . . . . . . . . . . . . . . . 5

5a Body depth at anus $9.7 \% L_{\mathrm{S}}$; depth of caudal peduncle $4.5 \% L_{\mathrm{S}}$; posterior margin of adipose fin rounded; genital papilla of male short and thick

5 b Body depth at anus $10 \cdot 0 \% L_{S}$; depth of caudal peduncle $5 \cdot 5 \% L_{S}$; posterior margin of adipose fin angular; genital papilla of male long and slender . . . . . . . . . . . . . . . . . . . . . . ischnosoma

6a Posterior edge of pectoral spine without serrations . . . . . . . . . . 7

$6 \mathrm{~b}$ Posterior edge of pectoral spine with serrations . . . . . . . . . . . 8

7 a Posterior margin of adipose fin rounded; length of dorsal-fin base $10 \cdot 8-13 \%$ $L_{\mathrm{S}}$; colour pattern generally consisting of small blotches of various shades of brown . . . . . . . . . . . . . . . . . . . . . A. falcifer

$7 \mathrm{~b}$ Posterior margin of adipose fin angular; length of dorsal-fin base $7 \cdot 9-10 \cdot 5 \%$ $L_{\mathrm{S}}$; colour pattern uniformly cream . . . . . . . . .A. pachyderma

8a Nasal barbels short $\left(1 \cdot 0-6 \cdot 0 \% L_{\mathrm{H}}\right)$; head with gently-sloping lateral margins and a broadly rounded snout when viewed dorsally . . . A. chamaeleon

8 b Nasal barbels long $\left(6 \cdot 5-23.9 \% L_{\mathrm{H}}\right)$; head narrow with steeply-sloping lateral margins and a convex snout when viewed dorsally. . .A. rugosus

ACROCHORDONICHTHYS ISCHNOSOMA BLEEKER, 1858 (FIG. 4)

Acrochordonichthys ischnosoma Bleeker, 1858: 232 (type locality: Tjitarum [=Citarum] River, Java); Bleeker, 1859: 136; Bleeker, 1862: 70, pl. 84, fig. 4; Günther, 1864: 96; Weber \& de Beaufort, 1913: 367; Kottelat et al., 1993: 74 (in part).

\section{Material examined}

BMNH 1863.12.11.151, 1 ex., holotype, 97.4 mm $L_{S}$; Java: Parongkalong, provinciae Preanger, in flumine Tjitarum. 


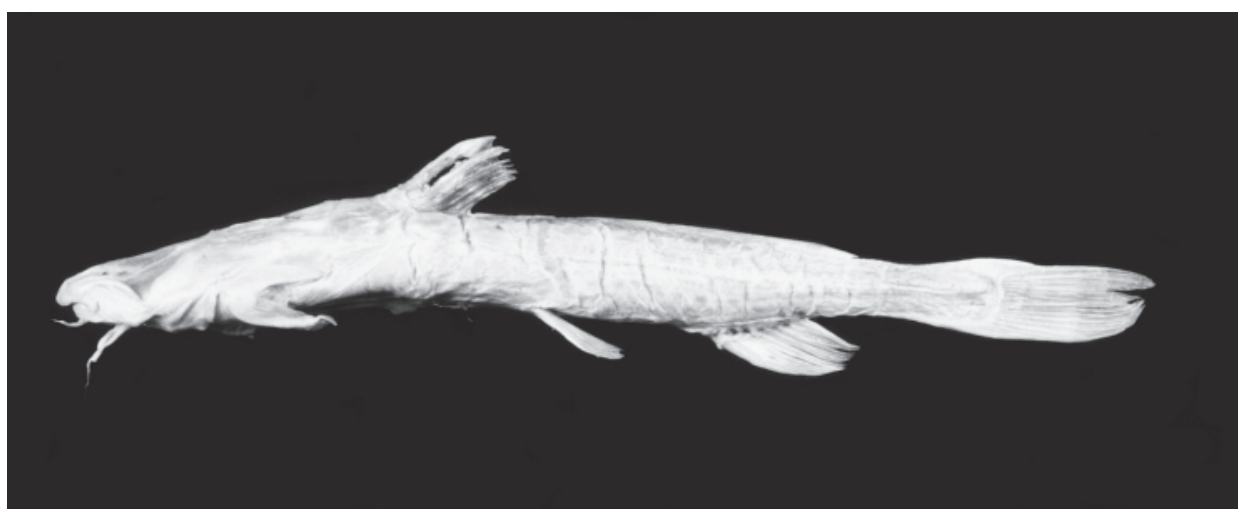

FIG. 4. Acrochordonichthys ischnosoma, BMNH 1863.12.11.151, holotype, 97.4 mm $L_{\mathrm{S}}$; Java: Citarum River drainage.
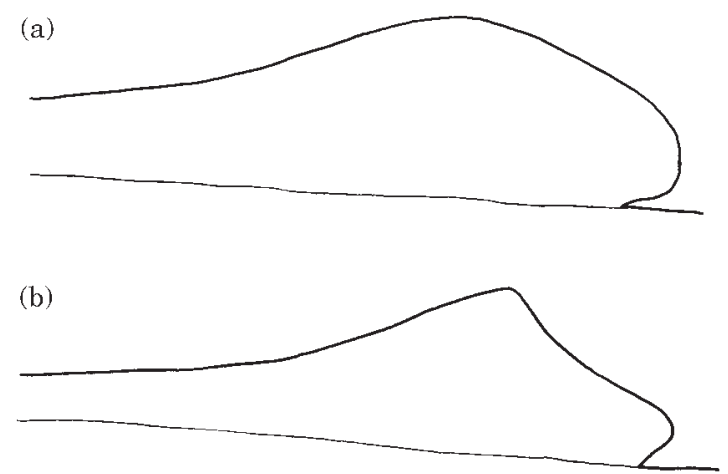

FIG. 5. Schematic illustration of posterior parts of adipose fins showing: (a) rounded posterior margin of Acrochordonichthys strigosus and A. falcifer (A. falcifer, ZRC 43323, paratype, $78.7 \mathrm{~mm} L_{\mathrm{S}}$ illustrated); (b) angular posterior margin of other Acrochordonichthys species (A. rugosus, ZRC $39290,93.6 \mathrm{~mm} L_{\mathrm{S}}$ illustrated).

\section{Differential diagnosis}

Acrochordonichthys ischnosoma can be differentiated from congeners of the A. ischnosoma species group by a greater dorsal to adipose distance $\left(9 \cdot 8 \% L_{\mathrm{S}} v\right.$. 4.4-8.7) and a longer snout (snout length $39 \cdot 0 \% L_{\mathrm{H}} v .28 \cdot 8-38 \cdot 4$ ). It can be further differentiated from $A$. guttatus in having a more slender body (body depth at anus $10.0 \% L_{\mathrm{S}} v .10 \cdot 9-12.8$ ) and a thicker humeral process (maximum width of humeral process $18 \cdot 4 \%$ its length $v$. 10.0-11.8); from A. mahakamensis by an angular ( $v$. rounded) anterior margin of the adipose fin (Fig. 5); from A. septentrionalis by a narrower head (18.3\% $L_{\mathrm{S}} v$. 19.6-21.9; Fig. 6); and from $A$. strigosus by an angular ( $v$. rounded) posterior margin of the adipose fin (Fig. 7) and a long, slender (v. short, thick) male genital papilla (Fig. 8).

\section{Description}

Head depressed, broad, body moderately compressed. Dorsal profile rising evenly but not steeply from tip of snout to origin of dorsal fin, then sloping gently ventrally from there to end of caudal peduncle. Ventral profile horizontal 
to origin of anal, then sloping dorsally to end of caudal peduncle. Head covered with small tubercles with poorly demarcated and indistinct margins, body with such tubercles arranged in five or six longitudinal rows on each side. Occipital process narrow, tip tapering, reaching interneural. Premaxillary toothband partially exposed when mouth closed. In $\% L_{\mathrm{S}}$ : head length $21 \cdot 9$, head width $18 \cdot 3$, head depth $10 \cdot 7$, predorsal distance $35 \cdot 4$, preanal length $69 \cdot 5$, prepelvic length $51 \cdot 0$, prepectoral length $24 \cdot 5$, body depth at anus $10 \cdot 0$, length of caudal peduncle $19 \cdot 6$, depth of caudal peduncle 5.5, pectoral-spine length $18 \cdot 4$, pectoral-fin length $18 \cdot 8$, length of dorsal-fin base $8 \cdot 5$, pelvic-fin length $11 \cdot 6$, length of anal-fin base $11 \cdot 1$, caudal-fin length $16 \cdot 7$, length of adipose-fin base $31 \cdot 2$, dorsal to adipose distance $9 \cdot 8$; in $\% L_{\mathrm{H}}$ : snout length $39 \cdot 0$, interorbital distance $34 \cdot 7$, eye diameter $4 \cdot 2$, length of nasal barbel $8 \cdot 9$, length of maxillary barbel $62 \cdot 0$, length of inner mandibular barbel 23.9, length of outer mandibular barbel 44.6. Branchiostegal rays 5 (1). Gill rakers $0+4$ (1). Vertebrae $20+19=39(1)$.

Fin ray counts: dorsal I,4,i (1); pectoral I,6,i (1); pelvic i,5 (1); anal iii,5,ii (1); caudal 7/6 (1). Dorsal fin origin nearer tip of snout than caudal flexure. Pectoral spine stout, with 7 (1) large serrations on posterior edge. Caudal fin weakly emarginate.

\section{Colouration}

Dorsal surface of head and body brown, with dark brown spots scattered randomly on dorsal surface of head. Belly, chest and ventral surface of head cream, without spots. Dorsal, pectoral, pelvic and anal fins cream with two dark brown bands, one at base of fins and another near edge. Caudal fin cream, with dark brown band near edge and dark brown patch at base of caudal peduncle. Barbels and pectoral spines cream, with dark brown spots on dorsal surfaces.

\section{Distribution}

Known only from the Citarum River drainage in western Java (Fig. 9).

\section{Remarks}

Acrochordonichthys ischnosoma is known only from the holotype (BMNH 1863.12.11:151), which is not well preserved and is somewhat dehydrated. This calls in question the diagnostic value of the morphometric characters used here. However, Acrochordonichthys and Breitensteinia have little flesh, especially on the dorsal surfaces, and so do not suffer much shrinkage from dehydration. Therefore the morphometric data obtained from old museum specimens are reasonably accurate, a supposition supported by present measurements of Bleeker specimens of other Acrochordonichthys species, which are in a similar state of preservation as the holotype of $A$. ischnosoma (see material examined for A. rugosus) and show no significant morphometric differences. Similarly, old museum specimens of Breitensteinia (that were not very well preserved) did not differ morphometrically from fresh ones of the same species ( $\mathrm{Ng} \&$ Siebert, 1998).

ACROCHORDONICHTHYS GUTTATUS SP. NOV. (FIG. 10)

Acrochordonichthys ischnosoma (non Bleeker)—de Pinna, 1996: 7. 
(a)

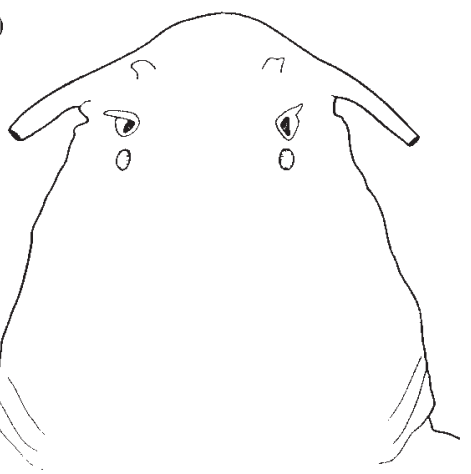

(c)

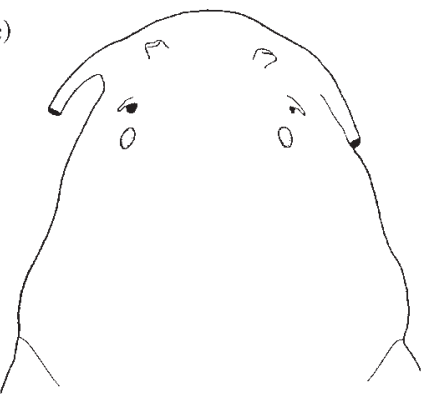

(b)

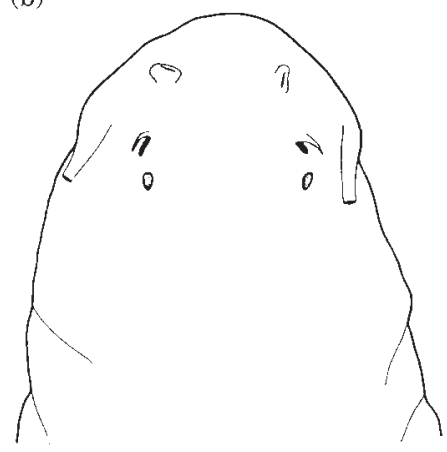

(d)

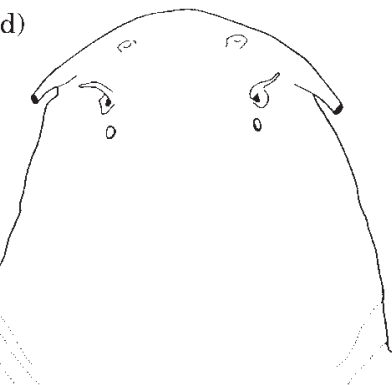

(e)

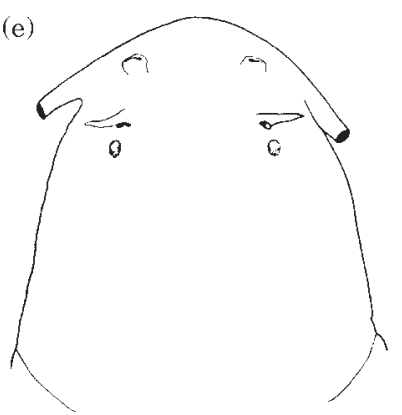

(f)

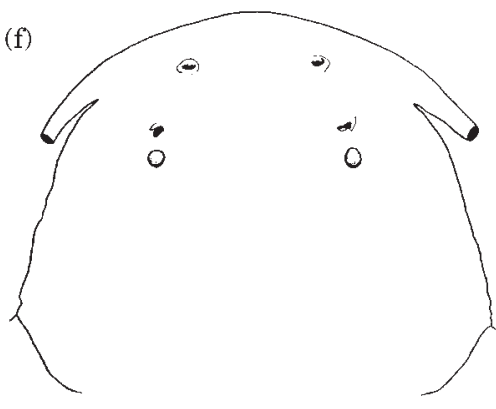

FIG. 6. (a-f).

\section{Holotype}

MZB 9301, 1 ex., 76.3 mm $L_{S}$; Borneo: Kalimantan Tengah, Barito River drainage, Sungai Barito at Muara Laung; D. Siebert, A. Tjakradiwdjaja \& O. Crimmen, 20-22 February 1991.

\section{Paratypes}

BMNH 1997.7.17.2, 1 ex., 75.6 mm $L_{\mathrm{S}}$; MZB 7024, 1 ex., 78.0 mm $L_{\mathrm{S}}$; Borneo: Kalimantan Tengah, Barito River drainage, Sungai Laung at Dessa Maruwei; 
(g)

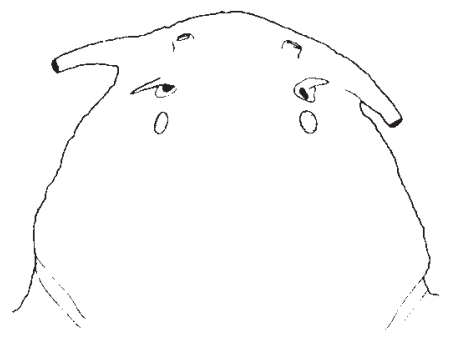

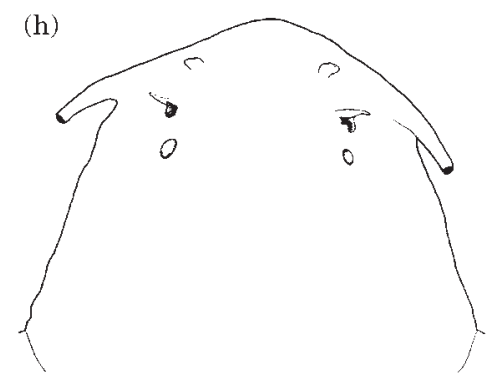

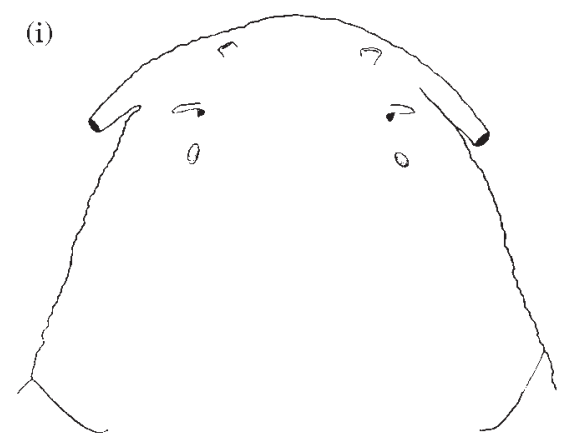

Fig. 6. (g-i).

FIG. 6 Dorsal view of heads of: (a) Acrochordonichthys guttatus, BMNH 1997.7.17.8, paratype, $97 \cdot 7 \mathrm{~mm}$ $L_{\mathrm{S}}$; (b) A. ischnosoma, BMNH 1863.12.11.151, holotype, $97.4 \mathrm{~mm} L_{\mathrm{S}}$; (c) A. mahakamensis, MZB 5952, holotype, $83.2 \mathrm{~mm} L_{\mathrm{S}}$; (d) A. septentrionalis, NIFI 3128 , holotype, $101.3 \mathrm{~mm} L_{\mathrm{S}}$; (e) A. strigosus, MZB 9333, holotype, $83.5 \mathrm{~mm} L_{\mathrm{S}}$; (f) A. chamaeleon, MZB 7553, 64.2 $\mathrm{mm} L_{\mathrm{S}}$;

(g) A. falcifer, ZRC 43323, paratype, $78 \cdot 8 \mathrm{~mm} L_{\mathrm{S}}$; (h) A. pachyderma, ZMA $119.419,94 \cdot 1 \mathrm{~mm} L_{\mathrm{S}}$;

(i) A. rugosus, ZRC $39290,93 \cdot 6 \mathrm{~mm} L_{\mathrm{S}}$.

D. Siebert, A. Tjakradiwdjaja \& O. Crimmen, 15-18 July 1992. BMNH 1997.7.17.8, 1 ex., 97.7 mm $L_{S}$; Borneo: Kalimantan Tengah, Barito River drainage, Sungai Teweh above Desa Lampeong II; A. Tjakradiwdjaja \& A. Mun'im, 2 October 1995. BMNH 1997.7.17.9-13, 6 ex., 63.5-83.9 mm $L_{\mathrm{S}}$; MZB 8187, 1 ex., 80.8 $\mathrm{mm} L_{\mathrm{S}}$; MZUSP 42468, 2 ex., 70·5-75.3 $\mathrm{mm} L_{\mathrm{S}}$; ZRC 41966, 2 ex., 74·1-77.7 $\mathrm{mm} L_{\mathrm{S}}$; data as for holotype. CMK 11847, 1 ex., $67 \cdot 0 \mathrm{~mm} L_{\mathrm{S}}$; Borneo: Kalimantan Tengah, middle Barito drainage, Barito River between Muara Jan and Muara Untu; M. Kottelat, 22 June 1995.

\section{Differential diagnosis}

Acrochordonichthys guttatus can be differentiated easily from congeners of the $A$. ischnosoma species group by a slender ( $v$. moderately thick) humeral process (maximum width $10 \cdot 0-11 \cdot 8 \%$ its length $v \cdot 13 \cdot 2-18 \cdot 4$ ). It can be differentiated further from $A$. ischnosoma by a smaller dorsal to adipose distance $\left(7 \cdot 7-8 \cdot 7 \% L_{\mathrm{S}}\right.$ v. 9.8), a longer and deeper head (head length $23 \cdot 2-26 \cdot 9 \% L_{\mathrm{S}} v .21 \cdot 9$; head depth $12 \cdot 7-14 \cdot 3 \% L_{\mathrm{S}} v \cdot 10 \cdot 7$ ) and a shorter snout (snout length $31 \cdot 4-38 \cdot 4 \% L_{\mathrm{H}} v .39 \cdot 0$ ); from $A$. mahakamensis by an angular ( $v$. rounded) anterior margin of the anal fin (Fig. 7); from $A$. septentrionalis by a larger dorsal to adipose distance $(7 \cdot 7-8 \cdot 7 \%$ $\left.L_{\mathrm{S}} v .4 \cdot 4-5 \cdot 7\right)$, more branchiostegal rays (6 v. 4) and a variegated colour pattern 
(a)
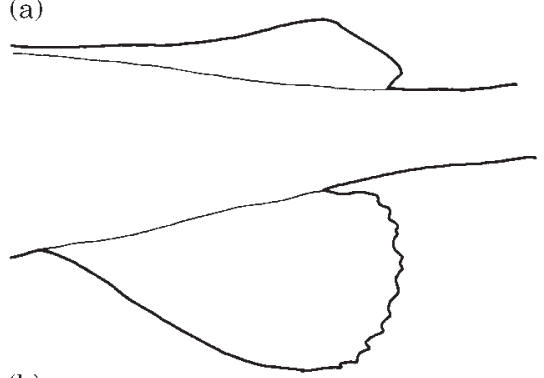

(b)
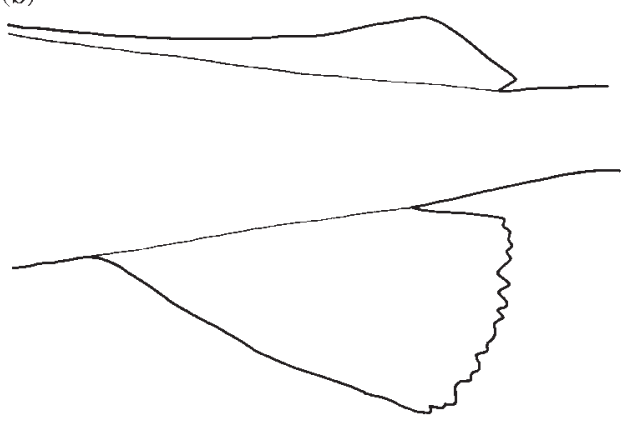

FIG. 7. Schematic illustration of anal fins showing: (a) rounded anterior margin of Acrochordonichthys mahakamensis (MZB 5952, holotype, $83.2 \mathrm{~mm} L_{\mathrm{S}}$ ); (b) angular anterior margin of other Acrochordonichthys species (A. guttatus, BMNH 1997.7.17.8, paratype, $97 \cdot 7 \mathrm{~mm} L_{\mathrm{S}}$ illustrated).
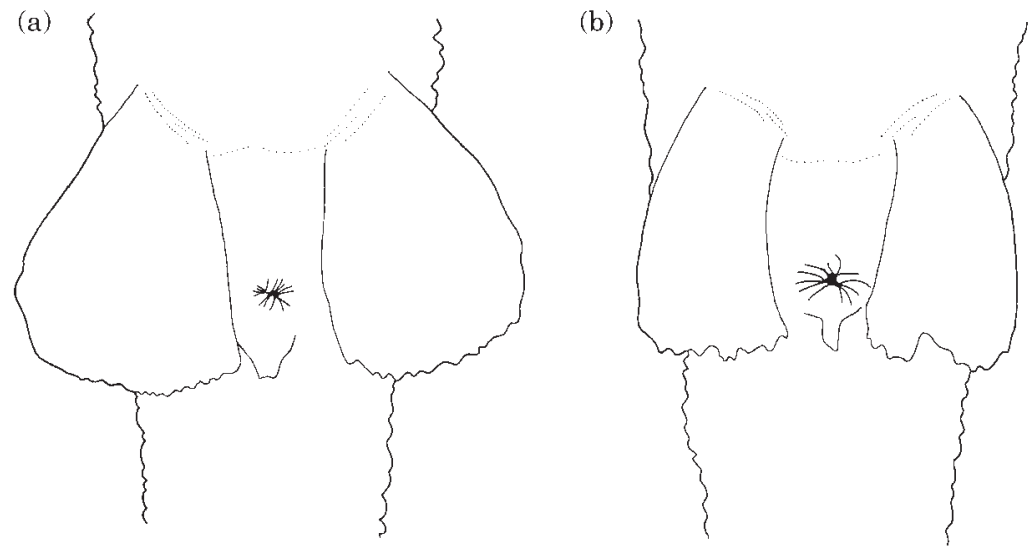

FIG. 8. Schematic illustration of male genital papilla in: (a) Acrochordonichthys strigosus (MZB 9333, holotype, $83.5 \mathrm{~mm} L_{\mathrm{S}}$ ); (b) other members of the A. ischnosoma species group (A. guttatus, BMNH 1997.7.17.8, paratype, $97 \cdot 7 \mathrm{~mm} L_{\mathrm{S}}$ illustrated).

with numerous brown patches ( $v$. almost uniformly cream colour pattern with few very small brown spots); and from $A$. strigosus by an angular ( $v$. rounded) posterior margin of the adipose fin (Fig. 5), a long, slender ( $v$. short, thick) male genital papilla (Fig. 8), and a relatively deeper body (body depth at anus $10 \cdot 9-12 \cdot 8 \% L_{\mathrm{S}}$ v. 9.7; depth of caudal peduncle $4 \cdot 7-5 \cdot 3 \% L_{\mathrm{S}} v .4 \cdot 5$ ). 


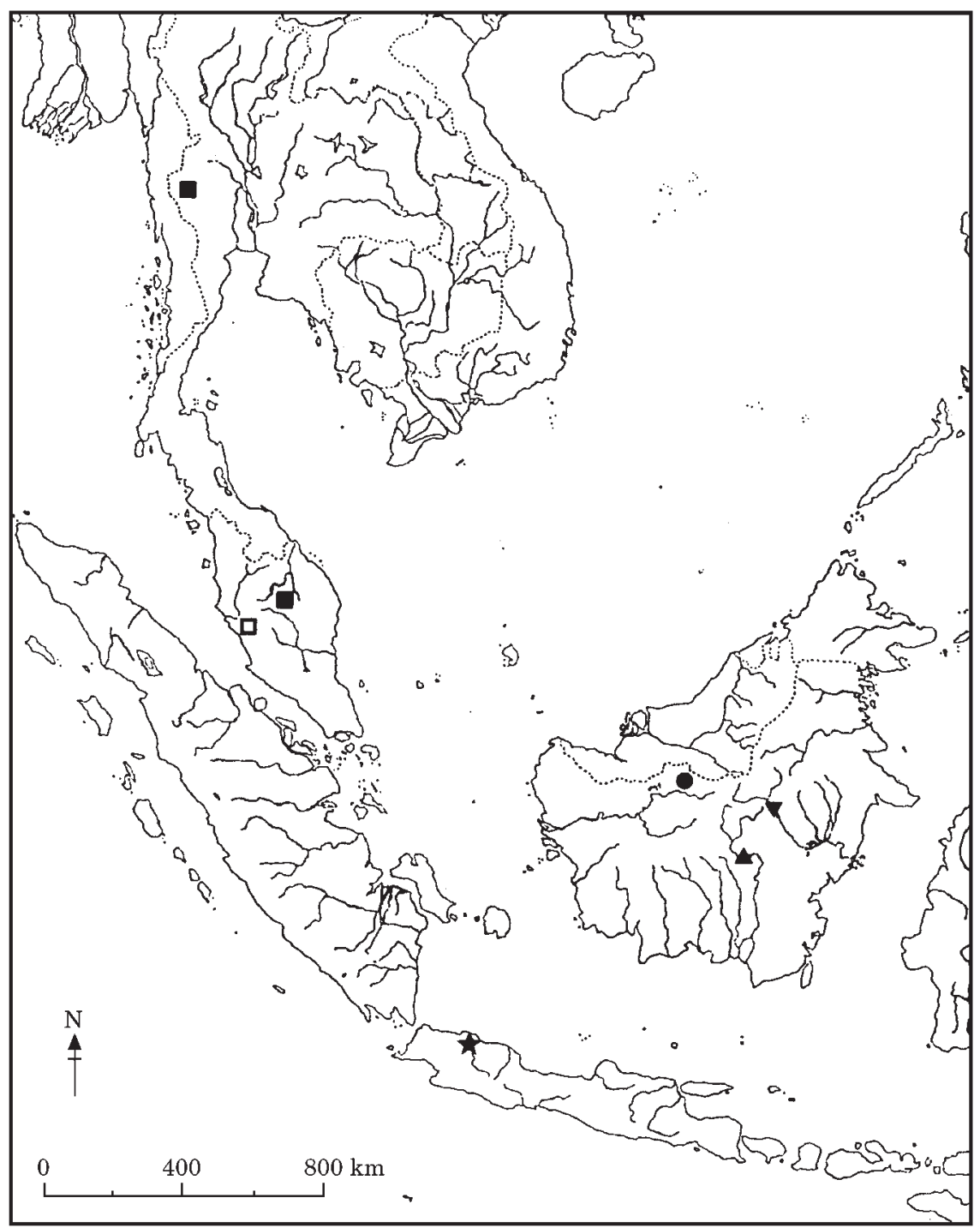

FIG. 9. Map showing distribution of members of Acrochordonichthys ischnosoma species group: $A$. ischnosoma $(\star)$; A. guttatus $(\mathbf{\Delta}) ;$ A. mahakamensis $(\boldsymbol{\nabla}) ;$ A. septentrionalis $(\boldsymbol{\square}) ;$ A. strigosus $(\mathbf{\bullet})$. Solid symbols represent records based on specimens; open symbols represent records based on literature.

\section{Description}

Head depressed, broad, body moderately compressed. Dorsal profile rising evenly but not steeply from tip of snout to origin of dorsal fin, then sloping gently ventrally from there to end of caudal peduncle. Ventral profile horizontal to origin of anal fin, then sloping dorsally to end of caudal peduncle. Head covered with small tubercles with poorly demarcated and indistinct margins, body with such tubercles arranged in five or six longitudinal rows on each side. Occipital process narrow, tip tapering, reaching interneural. Premaxillary 


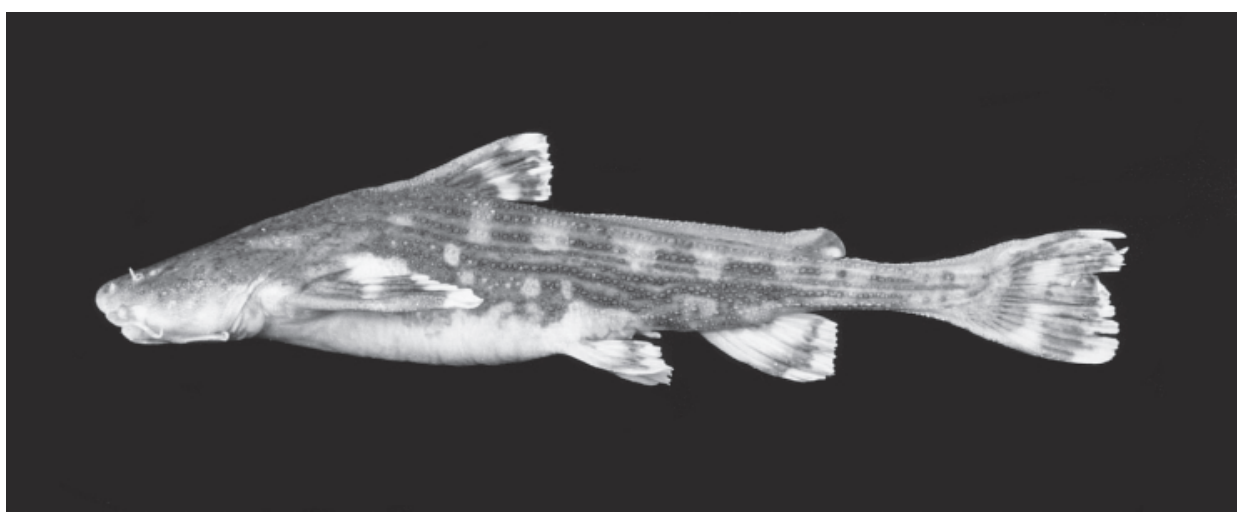

FIG. 10. Acrochordonichthys guttatus, BMNH 1997.7.17.8, paratype, $97 \cdot 7 \mathrm{~mm} L_{\mathrm{S}}$; Borneo: Barito River drainage.

toothband not exposed when mouth closed. In $\% L_{\mathrm{S}}$ : head length $23 \cdot 2-26 \cdot 9$,

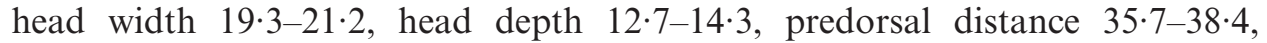
preanal length $66 \cdot 3-71 \cdot 4$, prepelvic length $51 \cdot 0-55 \cdot 9$, prepectoral length $22 \cdot 5-$ $27 \cdot 9$, body depth at anus $10 \cdot 9-12 \cdot 8$, length of caudal peduncle $19 \cdot 7-23 \cdot 1$, depth of caudal peduncle $4 \cdot 7-5 \cdot 3$, pectoral-spine length $17 \cdot 5-20 \cdot 9$, pectoral-fin length $21 \cdot 2-24 \cdot 3$, length of dorsal-fin base $8 \cdot 5-10 \cdot 4$, pelvic-fin length $11 \cdot 5-13 \cdot 4$, length of anal-fin base $9 \cdot 2-13 \cdot 8$, caudal-fin length $15 \cdot 5-19 \cdot 4$, length of adipose-fin base 28.2-32.6, dorsal to adipose distance 7.7-8.7; in $\% L_{\mathrm{H}}$ : snout length $31 \cdot 4-38 \cdot 4$, interorbital distance $30 \cdot 7-37 \cdot 7$, eye diameter $3 \cdot 5-5 \cdot 3$, length of nasal barbel $6 \cdot 2-9 \cdot 7$, length of maxillary barbel $49 \cdot 2-70 \cdot 7$, length of inner mandibular barbel $14 \cdot 8-28 \cdot 9$, length of outer mandibular barbel 33.9-54.7. Branchiostegal rays 6 (3). Gill rakers $0+4$ (2) or $0+6$ (1). Vertebrae $20+20=40$ (2), $21+19=40$ (7) or $21+20=41(1)$.

Fin ray counts: dorsal I,4,i (10); pectoral I,6,i (10); pelvic i,5 (10); anal ii,5,i (1), ii,6,i (6), iii,6,i (1), ii,7,i (1) or iii,7,i (1); caudal 7/6 (10). Dorsal origin nearer tip of snout than caudal flexure. Pectoral spine stout, with 6 (5)-7 (1) large serrations on posterior edge. Caudal fin weakly emarginate.

\section{Colouration}

Dorsal surface of head and body cream to dark yellow, with dark brown spots scattered randomly on dorsal surface of head. Dorsolateral and lateral surfaces of body dark brown, with about five cream or dark yellow spots on dorsolateral surface, sometimes forming a reticulate pattern. Belly, chest and ventral surface of head cream or dark yellow, without spots. Dorsal, pectoral, pelvic and anal fins cream with one or two dark brown bands, one occasionally present at base of fins and another near edge. Caudal fin cream, with dark brown band near edge and dark brown patch at base of caudal peduncle. Barbels and pectoral spines cream or dark yellow, with dark brown spots sometimes present on dorsal surfaces.

\section{Distribution}

Known only from the Barito River drainage in southern Borneo (Fig. 9). 


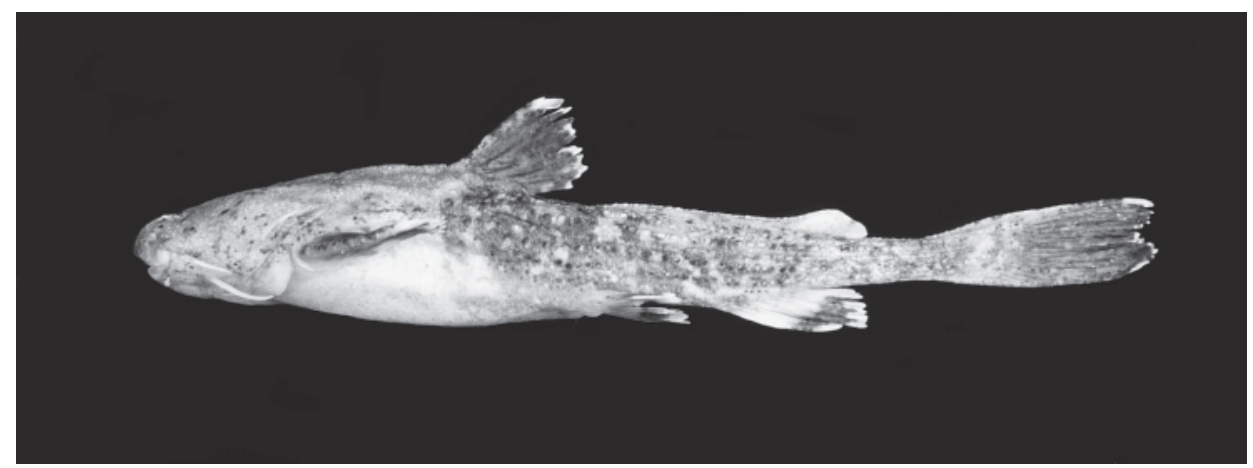

FIG. 11. Acrochordonichthys mahakamensis, MZB 5952, holotype, $83 \cdot 2 \mathrm{~mm} L_{\mathrm{S}}$; Borneo: Mahakam River drainage.

\section{Etymology}

From the Latin guttatus, meaning speckled; in reference to the pattern of small brown spots on the dorsal surface of the head and body.

ACROCHORDONICHTHYS MAHAKAMENSIS SP. NOV. (FIG. 11)

Acrochordonichthys cf. ischnosoma - Christensen, 1992: 601; Kottelat, 1994: 414.

\section{Holotype}

MZB 5952, 1 ex., 83.2 mm $L_{\mathrm{S}}$; Borneo: Kalimantan Timur, Mahakam River, boulders upstream of Melak ( $\left.0^{\circ} 12^{\prime} \mathrm{S} ; 115^{\circ} 47^{\prime} \mathrm{E}\right)$; M. Kottelat, 6 August 1991.

\section{Differential diagnosis}

Acrochordonichthys mahakamensis can be differentiated from congeners of the A. ischnosoma species group by a rounded ( $v$. angular) anterior margin of the anal fin (Fig. 7), and a relatively more slender body (body depth at anus $9 \cdot 4 \% L_{\mathrm{S}}$ v. 9.6-12.8; depth of caudal peduncle $4 \cdot 2 \% L_{\mathrm{S}} v .4 \cdot 5-5 \cdot 4$ ).

\section{Description}

Head depressed, broad, body moderately compressed. Dorsal profile rising evenly but not steeply from tip of snout to origin of dorsal fin, then sloping gently ventrally from there to end of caudal peduncle. Ventral profile horizontal to origin of anal fin, then sloping dorsally to end of caudal peduncle. Head covered with small tubercles with poorly demarcated and indistinct margins, body with such tubercles arranged in five to six longitudinal rows on each side. Occipital process narrow, tip tapering, reaching interneural. Premaxillary toothband not exposed when mouth closed. In $\% L_{\mathrm{S}}$ : head length $23 \cdot 8$, head width $21 \cdot 8$, head depth $13 \cdot 5$, predorsal distance $37 \cdot 3$, preanal length $67 \cdot 2$, prepelvic length $51 \cdot 8$, prepectoral length $24 \cdot 4$, body depth at anus $9 \cdot 4$, length of caudal peduncle $22 \cdot 0$, depth of caudal peduncle $4 \cdot 2$, pectoral-spine length $18 \cdot 4$, pectoral-fin length $21 \cdot 0$, length of dorsal-fin base $10 \cdot 0$, pelvic-fin length $12 \cdot 3$, length of anal-fin base $11 \cdot 5$, caudal-fin length $16 \cdot 0$, length of adipose-fin base $31 \cdot 5$, dorsal to adipose distance $8 \cdot 2$; in $\% L_{\mathrm{H}}$ : snout length $37 \cdot 4$, interorbital distance $31 \cdot 8$, eye diameter $4 \cdot 5$, length of nasal barbel $6 \cdot 1$, length of maxillary 


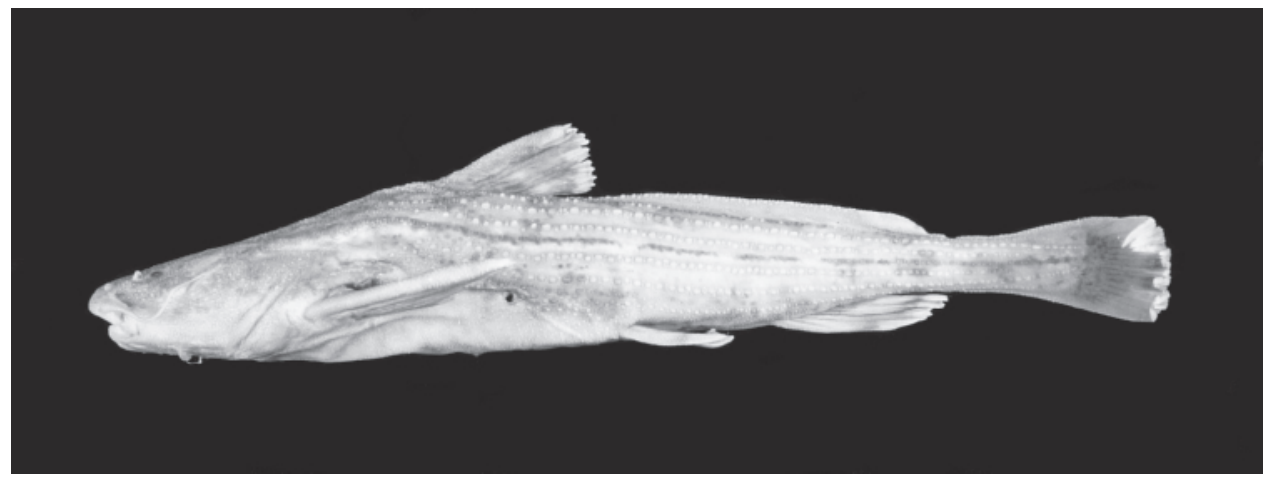

FIG. 12. Acrochordonichthys septentrionalis, NIFI 3128, holotype, $101.3 \mathrm{~mm} L_{\mathrm{S}}$; Thailand: Mae Khlong drainage.

barbel $63 \cdot 1$, length of inner mandibular barbel $17 \cdot 6$, length of outer mandibular barbel 41.9. Branchiostegal rays 6 (1). Gill rakers $1+4$ (1). Vertebrae $20+21=41(1)$.

Fin ray counts: dorsal I,4,i (1); pectoral I,6,i (1); pelvic i,5 (1); anal ii,6,I (1); caudal 7/6 (1). Dorsal origin nearer tip of snout than caudal flexure. Pectoral spine stout, with 6 (1) or 7 (1) large serrations on posterior edge. Caudal fin weakly emarginate.

\section{Colouration}

Dorsal surface of head and body cream, with dark brown spots scattered randomly on dorsal surface of head. Dorsolateral and lateral surfaces of body posterior to dorsal fin base with irregular dark brown blotches. Belly, chest and ventral surface of the head cream, without spots. Dorsal and pectoral fins dark brown, with cream distal margins. Pelvic and anal fins cream with a dark brown band near edge. Caudal fin cream, with dark brown band near edge and dark brown patch at base of caudal peduncle. Barbels and pectoral spines cream, with dark brown spots on dorsal surfaces.

\section{Distribution}

Known only from the Mahakam River drainage in eastern Borneo (Fig. 9).

\section{Etymology}

The name refers to the type locality of this species (the Mahakam River).

\section{ACROCHORDONICHTHYS SEPTENTRIONALIS SP. NOV. (Fig. 12)}

Acrochordonichthys ischnosoma (non Bleeker)-Hora \& Gupta, 1941: 29, figs 4-5; (?) Mohsin \& Ambak, 1982: 101, fig. 1; (?) Mohsin \& Ambak, 1983: 122, fig. 89; Zakaria-Ismail, 1984: 25; Kottelat et al., 1993: 74, pl. 36 (in part); Lim et al., 1993: 7; (?) Vidthayanon et al., 1998: 46.

\section{Holotype}

NIFI 3128, 101.3 $\mathrm{mm} L_{\mathrm{S}}$; Thailand: Kanchanaburi province, Kwae Noi River; collector unknown, 10 April 1975. 


\section{Paratypes}

NIFI 3129, 2 ex., 88.4-91.0 $\mathrm{mm} L_{S}$; data as for holotype. ZRC 2341, 1 ex., 95.5 mm $L_{S}$; Malaysia: Pahang, King George V National Park; E. O. Shebbeare, 1939. ZRC 2360, 1 ex., 99.4 mm $L_{S}$; Malaysia: Pahang, Kuala Tahan; M. W. F. Tweedie, April 1940.

\section{Differential diagnosis}

Acrochordonichthys septentrionalis can be differentiated from congeners of the A. ischnosoma species group by a smaller dorsal to adipose distance $\left(4 \cdot 4-5 \cdot 7 \% L_{\mathrm{S}}\right.$ v. 6.2-9.8), fewer branchiostegal rays (4 v. 5-6) and an almost uniformly cream colour pattern with few very small brown spots ( $v$. variegated colour pattern with numerous brown patches).

\section{Description}

Head depressed, broad, body moderately compressed. Dorsal profile rising evenly but not steeply from tip of snout to origin of dorsal fin, then sloping gently ventrally from there to end of caudal peduncle. Ventral profile horizontal to origin of anal fin, then sloping dorsally to the end of caudal peduncle. Head covered with small tubercles with poorly demarcated and indistinct margins, body with such tubercles arranged in five or six longitudinal rows on each side. Occipital process narrow, tip tapering, reaching interneural. Premaxillary toothband not exposed when mouth closed. In $\% L_{\mathrm{S}}$ : head length $22 \cdot 0-24 \cdot 4$, head width 19.6-21.9, head depth $12 \cdot 8-15 \cdot 8$, predorsal distance $34 \cdot 2-37 \cdot 8$, preanal length $67 \cdot 0-72 \cdot 9$, prepelvic length $51 \cdot 0-56 \cdot 7$, prepectoral length $20 \cdot 9$ $25 \cdot 5$, body depth at anus $9 \cdot 6-12 \cdot 4$, length of caudal peduncle $20 \cdot 0-21 \cdot 5$, depth of caudal peduncle $4 \cdot 9-5 \cdot 4$, pectoral-spine length $16 \cdot 1-20 \cdot 8$, pectoral-fin length $20 \cdot 4-22 \cdot 9$, length of dorsal-fin base $8 \cdot 4-9 \cdot 9$, pelvic-fin length $10 \cdot 9-12 \cdot 7$, length of anal-fin base $10 \cdot 2-11 \cdot 9$, caudal-fin length $15 \cdot 0-17 \cdot 3$, length of adipose-fin base 30.9-33.9, dorsal to adipose distance 4.4-8.6; in $\% L_{\mathrm{H}}$ : snout length $28 \cdot 8-35 \cdot 4$, interorbital distance $31 \cdot 5-35 \cdot 2$, eye diameter $4 \cdot 3-6 \cdot 9$, length of nasal barbel $6 \cdot 9-11 \cdot 8$, length of maxillary barbel $65 \cdot 0-77 \cdot 3$, length of inner mandibular barbel $20 \cdot 7-27 \cdot 0$, length of outer mandibular barbel $51 \cdot 7-53 \cdot 7$. Branchiostegal rays 4 (3) or 6 (2). Gill rakers $1+3$ (2) or $1+4$ (2). Vertebrae $19+21=40$ (2) or $20+20=40(1)$.

Fin ray counts: dorsal I,4,i (5); pectoral I,6,i (5); pelvic i,5 (5); anal ii,5,i (1) or iii,6,i (4); caudal 7/6 (5). Dorsal origin nearer tip of snout than caudal flexure. Pectoral spine stout, with 5 (2), 6 (1) or 7(2) large serrations on posterior edge. Caudal fin weakly emarginate.

\section{Colouration}

Dorsal surface of head and body cream with dark brown spots scattered randomly on dorsal surface of head. Dorsolateral and lateral surfaces of body cream with small dark brown patches on dorsolateral surface. Belly, chest and ventral surface of head cream or dark yellow, without spots. Dorsal and pectoral fins brown with a hyaline distal margin. Pelvic and anal fins hyaline with a brown band in middle of fin. Caudal fin cream, with dark brown band near edge 


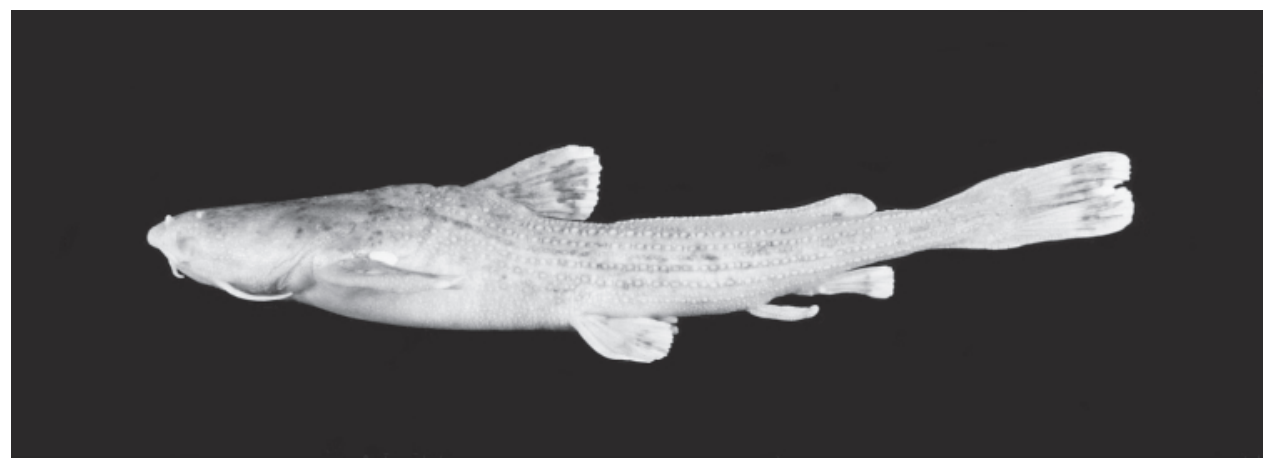

FIG. 13. Acrochordonichthys strigosus, MZB 9333, holotype, $83.5 \mathrm{~mm} L_{\mathrm{S}}$; Borneo: Kapuas River drainage.

and dark brown patch at base of caudal peduncle connected by thin brown longitudinal stripe. Barbels and pectoral spines cream or dark yellow, with dark brown spots sometimes present on dorsal surfaces.

\section{Distribution}

Known only from the Mae Khlong River drainage in Thailand and the Pahang River drainage in Peninsular Malaysia; it may be found in the Bernam River drainage in Peninsular Malaysia (Fig. 9).

\section{Etymology}

From the Latin septentrionalis, meaning northern, in reference to the distribution of this species.

\section{Remarks}

The record of $A$. septentrionalis from the Bernam River in western Peninsular Malaysia by Davies \& Abdullah (1989) is based on a photograph seen by the second author; the present disposition of this specimen remains unknown. The photograph of $A$. ischnosoma provided in Kottelat et al. (1993) is that of $A$. septentrionalis and the record of $A$. ischnosoma from the Chao Phraya by Vidthayanon et al. (1998) may refer to this species as well.

ACROCHORDONICHTHYS STRIGOSUS SP. NOV. (FIG. 13)

\section{Holotype}

MZB 9333, 1 ex., 83.5 mm $L_{\mathrm{S}}$; Borneo: Kalimantan Barat, Sungai Sibau, from mouth of Sungai Putan to $3 \mathrm{~km}$ downstream $\left(1^{\circ} 2^{\prime} 28 \cdot 0^{\prime \prime} \mathrm{N} 112^{\circ} 59^{\prime} 58 \cdot 6^{\prime \prime} \mathrm{E}\right)$; Y. Y. Goh et al., 5 May 1998.

\section{Differential diagnosis}

Acrochordonichthys strigosus can be differentiated from congeners of the $A$. ischnosoma species group by a rounded ( $v$. angular) posterior margin of the adipose fin (Fig. 5) and a relatively more slender body (body depth at anus $9 \cdot 7 \%$ $L_{\mathrm{S}}$ v. 9.6-12.8; depth of caudal peduncle $\left.4 \cdot 5 \% L_{\mathrm{S}} v \cdot 4 \cdot 7-5 \cdot 4\right)$. The genital papilla 
in male A. strigosus is also morphologically different from other members of the A. ischnosoma species group (short and thick v. long and thin; Fig. 8).

\section{Description}

Head depressed, broad, body moderately compressed. Dorsal profile rising evenly but not steeply from tip of snout to origin of dorsal fin, then sloping gently ventrally from there to end of caudal peduncle. Ventral profile horizontal to origin of anal fin, then sloping dorsally to end of caudal peduncle. Head covered with small tubercles with poorly demarcated and indistinct margins, body with such tubercles arranged in five or six longitudinal rows on each side. Occipital process narrow, tip tapering, reaching interneural. Premaxillary toothband not exposed when mouth closed. In $\% L_{\mathrm{S}}$ : head length $22 \cdot 6$, head width $20 \cdot 5$, head depth $12 \cdot 0$, predorsal distance $36 \cdot 4$, preanal length $69 \cdot 2$, prepelvic length $50 \cdot 5$, prepectoral length $24 \cdot 3$, body depth at anus $9 \cdot 7$, length of caudal peduncle $21 \cdot 4$, depth of caudal peduncle $4 \cdot 5$, pectoral-spine length $21 \cdot 0$, pectoral-fin length $23 \cdot 1$, length of dorsal-fin base $8 \cdot 4$, pelvic-fin length $11 \cdot 4$, length of anal-fin base $11 \cdot 4$, caudal-fin length $16 \cdot 8$, length of adipose-fin base $30 \cdot 2$, dorsal to adipose distance $7 \cdot 2$; in $\% L_{\mathrm{H}}$ : snout length $39 \cdot 2$, interorbital distance $36 \cdot 5$, eye diameter $5 \cdot 3$, length of nasal barbel $9 \cdot 5$, length of maxillary barbel $77 \cdot 2$, length of inner mandibular barbel $37 \cdot 6$, length of outer mandibular barbel 52.4. Branchiostegal rays 5 (1). Gill rakers 1+3 (1). Vertebrae $20+20=40(1)$.

Fin ray counts: dorsal I,4,i (1); pectoral I,6,i (1); pelvic i,5 (1); caudal 7/6 (1). Dorsal origin nearer tip of snout than caudal flexure. Pectoral spine stout, with 6 (1) or 7 (1) large serrations on posterior edge. Caudal fin weakly emarginate.

\section{Colouration}

Dorsal and lateral surfaces of head and body brown, with dark brown spots scattered randomly on dorsal surface of head. Belly, chest and ventral surface of head cream, without spots. Dorsal, pectoral, pelvic and anal fins cream with dark brown band near edge. Caudal fin cream, with dark brown band near edge and dark brown patch at base of caudal peduncle. Barbels and pectoral spines cream, with dark brown spots on dorsal surfaces.

\section{Distribution}

Known only from the Kapuas River drainage in western Borneo (Fig. 9).

\section{Etymology}

From the Latin strigosus, meaning slender; in reference to the relatively slender body of this species.

ACROCHORDONICHTHYS CHAMAELEON (VAILLANT, 1902) (FIG. 14)

Sosia chamaeleon Vaillant, 1902: 82, figs 19-21 (in part) (type locality: Mandai and Sibau Rivers, Kapuas basin, Borneo); Bertin \& Estève, 1950: 32.

Sosia chamaleon-Weber \& de Beaufort, 1913: 370.

Acrochordonichthys chamaleon-Roberts, 1989: 137, fig. 105; Kottelat et al., 1993: 74, fig. 171. 


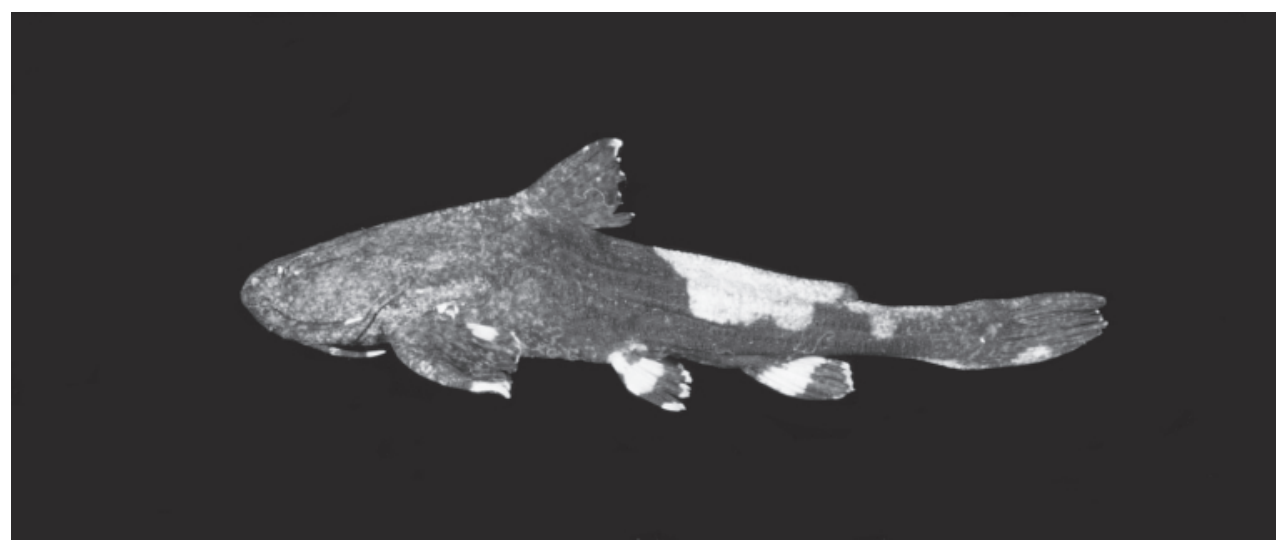

FIG. 14. Acrochordonichthys chamaeleon, ZRC 38830, $51.5 \mathrm{~mm} L_{\mathrm{S}}$; Borneo: Kapuas River drainage.

Acrochordonichthys chamaeleon-Ng \& Rachmatika, 1999: 169, figs 2-3a.

\section{Material examined}

RMNH 7849, 1 ex., lectotype, 90.0 $\mathrm{mm} L_{\mathrm{S}}$; Borneo: Raoen/Mandai. RMNH 7851, 3 ex., paralectotypes, 57·5-98.0 $\mathrm{mm} L_{\mathrm{S}}$; Borneo: Sibau. CMK 6899, 2 ex., 34.1-76.9 $\mathrm{mm} L_{\mathrm{S}}$; Borneo: Kalimantan Barat, Kapuas River drainage, Sungai Sibau where it splits into two branches, c. $2 \mathrm{~km}$ upstream of Putussibau. CMK 11711, 5 ex., 37.5-96.8 mm $L_{\mathrm{S}}$; ZRC 38830, 1 ex., $51.5 \mathrm{~mm} L_{\mathrm{S}}$; Borneo: Kalimantan Barat, Kapuas River drainage, Danau Sentarum area, Sungai Hulu Leboyan at Keluwin. MZB 7553, 1 ex., 64.2 mm $L_{S}$; Borneo: Kalimantan Barat, Kapuas River drainage, Sungai Putan, a tributary of Sungai Sibau. MZB 9423, 1 ex., 83.0 mm $L_{S}$; Borneo: Kalimantan Barat, Kapuas River drainage, Sungai Mendalam. MZB 9431, 1 ex., 97.9 mm $L_{S}$; Borneo: Kalimantan Barat, Kapuas River drainage, Sungai Mentibat, a tributary of Sungai Mendalam.

\section{Differential diagnosis}

Acrochordonichthys chamaeleon can be differentiated from congeners of the A. rugosus species group by shorter nasal barbels $\left(1 \cdot 0-6 \cdot 0 \% L_{\mathrm{H}}\right.$ v. 6.5-23.9), wide-set eyes (interorbital distance $38 \cdot 9-47 \cdot 5 \% L_{\mathrm{H}}$ ), a head with gently-sloping lateral margins and a broadly rounded snout when viewed dorsally (Fig. 6).

\section{Description}

Head depressed, broad, body moderately compressed. Dorsal profile rising evenly but not steeply from tip of snout to origin of dorsal fin, then sloping gently ventrally from there to end of caudal peduncle. Ventral profile horizontal to origin of anal fin, then sloping dorsally to end of caudal peduncle. Head covered with small tubercles with poorly demarcated and indistinct margins, body with such tubercles arranged in five or six longitudinal rows on each side. Occipital process narrow, tip tapering, reaching interneural. Premaxillary toothband not exposed when mouth closed. In $\% L_{\mathrm{S}}$ : head length $23 \cdot 7-31 \cdot 6$,

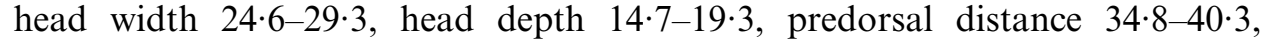
preanal length $68 \cdot 5-73 \cdot 6$, prepelvic length $50 \cdot 8-56 \cdot 5$, prepectoral length $23 \cdot 1-$ $28 \cdot 4$, body depth at anus $12 \cdot 3-14 \cdot 7$, length of caudal peduncle $19 \cdot 9-23 \cdot 0$, depth 
of caudal peduncle $5 \cdot 0-6 \cdot 1$, pectoral-spine length $20 \cdot 9-22 \cdot 3$, pectoral-fin length $23 \cdot 3-26 \cdot 2$, length of dorsal-fin base $8 \cdot 6-10 \cdot 3$, pelvic-fin length $11 \cdot 0-13 \cdot 7$, length of anal-fin base $9 \cdot 1-12 \cdot 1$, caudal-fin length $15 \cdot 6-20 \cdot 1$, length of adipose-fin base 27.8-31·7, dorsal to adipose distance 5.6-9.0; in $\% L_{\mathrm{H}}$ : snout length $31 \cdot 3-41 \cdot 9$, interorbital distance $38 \cdot 9-47 \cdot 5$, eye diameter $3 \cdot 6-7 \cdot 3$, length of nasal barbel $1 \cdot 0-6 \cdot 0$, length of maxillary barbel $53 \cdot 2-71 \cdot 5$, length of inner mandibular barbel $19 \cdot 5-37 \cdot 8$, length of outer mandibular barbel 39.5-50.3. Branchiostegal rays 5 (1) or 6 (1). Gill rakers $1+4(1)$. Vertebrae $17+18=35$ (1) or $18+18=36$ (1).

Fin ray counts: dorsal I,4,i (6); pectoral I,6,i (4), I,7 (1) or I,7,I (1); pelvic i,5 (6); anal ii,4,I (1), ii,5,I (4) or ii,7 (1); caudal 6/6 (2) or 7/6 (4). Dorsal origin nearer tip of snout than caudal flexure. Pectoral spine stout, with 3 (1) serrations on posterior edge. Caudal fin weakly emarginate.

\section{Colouration}

Dorsal surface of head and body chestnut brown, sometimes with small dark brown patches scattered randomly on dorsal surface of head. Dorsolateral, lateral and sometimes ventral surfaces of body posterior to dorsal-fin base dark brown, with a chestnut brown saddle on dorsolateral surface over adipose fin. In some specimens, saddle is absent, replaced by longitudinal series of chestnut brown spots, coalescing to form patches. Belly, chest and ventral surface generally lighter in colour, without spots. Dorsal, pectoral, pelvic and anal fins cream with one or two dark brown bands, one occasionally present at base of fins and another near edge. In some specimens, colour pattern of fins is reversed and fins are overall dark brown with cream bands. Caudal fin cream, with dark brown band near edge and dark brown patch at base of caudal peduncle. Barbels and pectoral spines cream or dark yellow, with dark brown spots sometimes present on dorsal surfaces. Some specimens overall dark brown throughout and lack both spots and saddle.

\section{Distribution}

Known only from the Kapuas River drainage in western Borneo (Fig. 15).

\section{Remarks}

Vaillant (1902) described Sosia chamaeleon and a subspecies, S. chamaeleon var. pallida, from the Kapuas River drainage in western Borneo. Roberts (1989) was the first to suggest that the type series consisted of two species and present examination of the syntypes has since corroborated this, with the smaller specimens referable to $A$. rugosus and the larger to $A$. chamaeleon. To stabilize the name $A$. chamaeleon, RMNH 7849 is designated as the lectotype for Sosia chamaeleon and RMNH 7848 for Sosia chamaeleon var. pallida in accordance to Article 75 of the International Code for Zoological Nomenclature (International Commission for Zoological Nomenclature, 1999).

This species, previously considered a synonym of $A$. melanogaster (itself considered a synonym of $A$. rugosus here) by Weber \& de Beaufort (1913), was regarded as a valid species by Roberts (1989), who differentiated it from all other Acrochordonichthys species by a relatively wide head, extremely short nasal barbels, absence of tubercles on nearly the entire caudal fin and a pale-coloured 


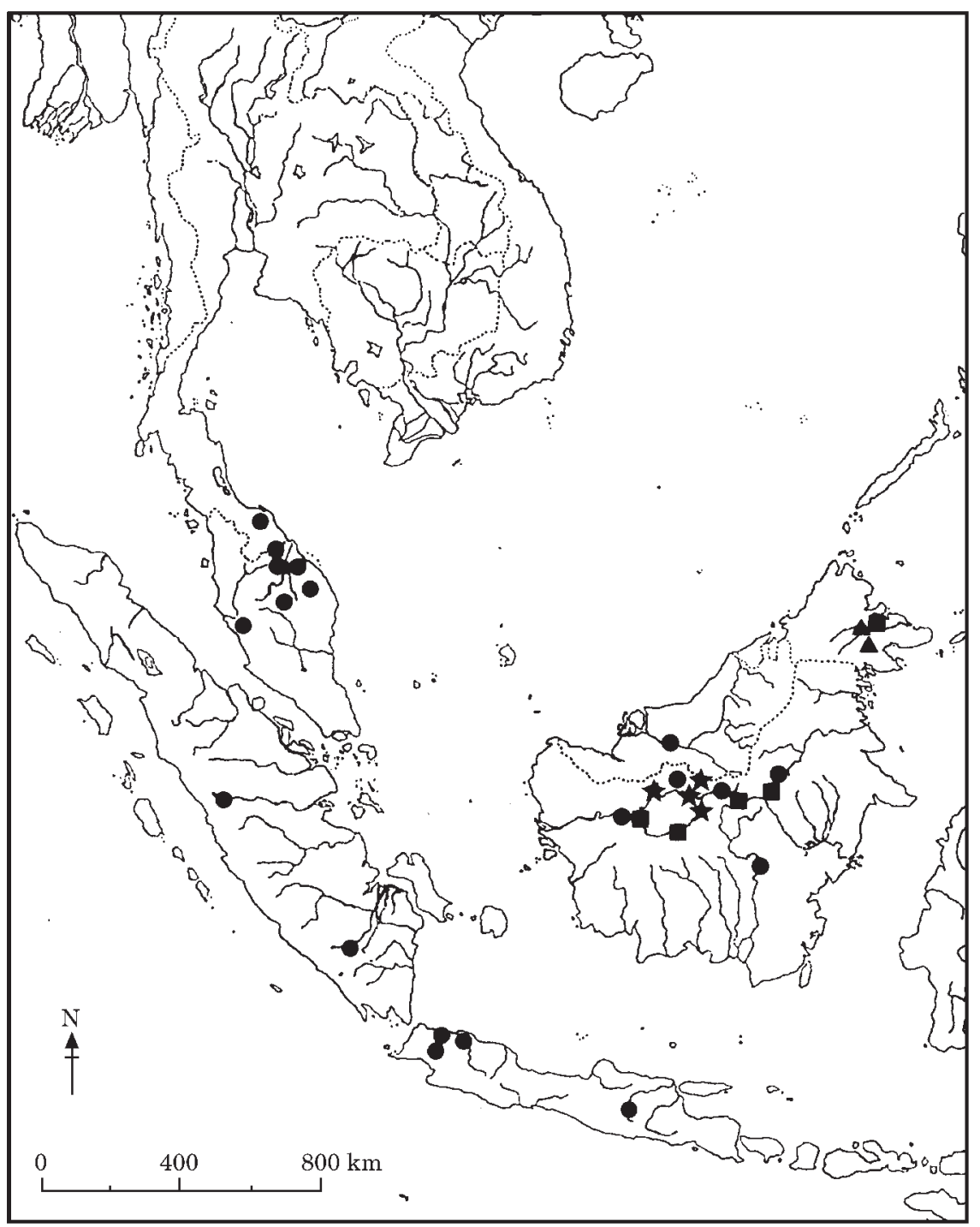

FIG. 15. Map showing distribution of members of Acrochordonichthys rugosus species group: $A$. chamaeleon $(\star)$; A. falcifer $(\mathbf{\Delta})$, A. pachyderma $(\mathbf{\square})$; A. rugosus $(\mathbf{0})$.

snout and occipital region. Present examination of the types and fresh material indicates that only the broad head (whose appearance is due to the gently-sloping lateral margins) and extremely short nasal barbels are useful diagnostic characters for this species. There is no trace of any pale colour on the snout or occipital region, and considering the fact that considerable colour variation exists in members of this genus (possibly related to the phenomenon of skin moulting, see above), it is to be expected that colour is not a useful diagnostic character. Also, tubercles were present on the caudal-fin rays of fresh specimens of $A$. chamaeleon and their absence in the type specimens examined by Roberts (1989) may have 


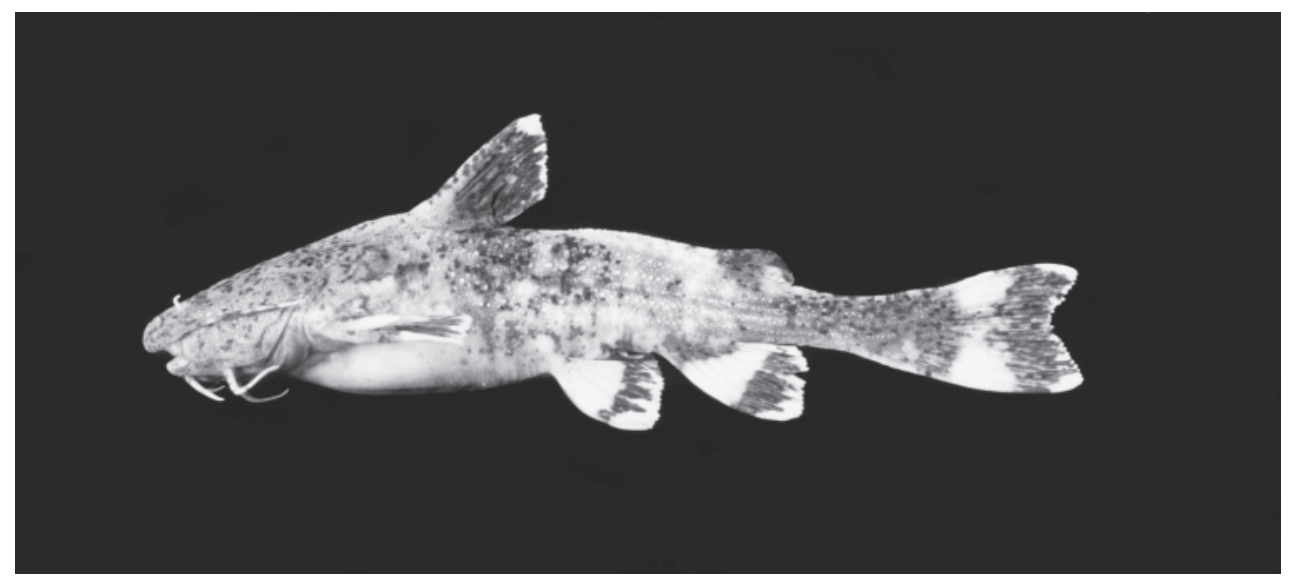

FIG. 16. Acrochordonichthys falcifer, SSM, paratype, $68.6 \mathrm{~mm} L_{\mathrm{S}}$, Borneo: Segama River drainage.

been due to loss through inadequate preservation and long-term storage in alcohol.

ACROCHORDONICHTHYS FALCIFER SP. NOV. (FIG. 16)

Acrochordonichthys melanogaster (non Bleeker) - Inger \& Chin, 1962: 134, fig. 67; Lim \& Wong, 1994: 55.

Acrochordonichthys obscurus (non Popta)_Martin-Smith \& Tan, 1998: 591, fig. 12.

(?) Acrochordinichthys [sic] pachyderma-Rendahl, 1922: 201.

\section{Holotype}

ZRC 43321, 76.6 mm $L_{S}$; Borneo: Sabah, Sungai Segama; K. Martin-Smith, 5 December 1996.

\section{Paratypes}

FMNH 68008, 1 ex., 79.5 mm $L_{S}$; Borneo: Sabah, East Coast Residency, Kinabatangan District, Deramakot Camp, Kinabatangan River; R. F. Inger, 12 May 1956. FMNH 68009, 4 ex., 30.0-41.3 mm $L_{S}$; Borneo: Sabah, Kinabatangan District, Deramakot Camp, Kinabatangan River, below mouth of Malubok River; R. F. Inger, 8 May 1956. ZRC 43322, 1 ex., $92 \cdot 1 \mathrm{~mm} L_{\mathrm{S}}$; Borneo: Sabah, Sungai Segama, opposite Palum Tambun; K. Martin-Smith, 27 November 1996. ZRC 43323, 2 ex., 66.5-78.8 mm $L_{S}$; Borneo: Sabah, Sungai Segama; K. Martin-Smith, 5 December 1996. ZRC 43324, 1 ex., 74.8 mm $L_{\mathrm{S}}$; SSM, 2 ex., $68 \cdot 1-68 \cdot 6 \mathrm{~mm} L_{S}$; data as for holotype.

\section{Differential diagnosis}

Acrochordonichthys falcifer can be differentiated from congeners of the $A$. rugosus species group by an adipose fin with a rounded ( $v$. angular) posterior margin (Fig. 5) and a longer dorsal-fin base $\left(10 \cdot 8-13 \cdot 1 \% L_{\mathrm{S}}\right.$ v. $\left.7 \cdot 9-10 \cdot 5\right)$. Generally the colour pattern of $A$. falcifer is also different in having many small blotches ( $v$. few large blotches) of various shades of brown, with many small dark brown spots ( $v$. no spots) on the dorsal surfaces of the head. Both A. falcifer and 
A. pachyderma lack serrations on the pectoral spine, but the two species can be separated based on their colouration (cream with numerous small blotches of various shades of brown in A. falcifer $v$. overall cream in A. pachyderma) and the shape of the posterior margin of the adipose fin (see above).

\section{Description}

Head depressed and broad, body moderately compressed. Dorsal profile rising evenly but not steeply from tip of snout to origin of dorsal fin, then sloping gently ventrally from there to end of caudal peduncle. Ventral profile horizontal to origin of anal fin, then sloping dorsally to end of caudal peduncle. Head covered with small tubercles with poorly demarcated and indistinct margins, body with such tubercles arranged in five or six longitudinal rows on each side. Occipital process narrow, its tip tapering and reaching interneural. Premaxillary toothband not exposed when mouth is closed. In $\% L_{\mathrm{S}}$ : head length $22 \cdot 4-28 \cdot 0$, head width $24 \cdot 0-28 \cdot 6$, head depth $14 \cdot 5-19 \cdot 5$, predorsal distance $36 \cdot 7-40 \cdot 8$, preanal length $67 \cdot 1-71 \cdot 8$, prepelvic length $51 \cdot 0-56 \cdot 5$, prepectoral length $22 \cdot 3$ $30 \cdot 2$, body depth at anus $10 \cdot 9-13 \cdot 6$, length of caudal peduncle $20 \cdot 1-22 \cdot 5$, depth of caudal peduncle $5 \cdot 4-6 \cdot 6$, pectoral-spine length $16 \cdot 2-22 \cdot 0$, pectoral-fin length $20 \cdot 1-25 \cdot 8$, length of dorsal-fin base $10 \cdot 8-13 \cdot 1$, pelvic-fin length $12 \cdot 9-15 \cdot 0$, length of anal-fin base $9 \cdot 4-10 \cdot 9$, caudal-fin length $16 \cdot 3-20 \cdot 3$, length of adipose-fin base $25 \cdot 7-31 \cdot 8$, dorsal to adipose distance $5 \cdot 5-7 \cdot 7$; in $\% L_{\mathrm{H}}$ : snout length $36 \cdot 8-40 \cdot 9$, interorbital distance $34 \cdot 1-38 \cdot 4$, eye diameter $5 \cdot 4-8 \cdot 1$, length of nasal barbel $7 \cdot 4-13 \cdot 0$, length of maxillary barbel $67 \cdot 8-92 \cdot 9$, length of inner mandibular barbel $19 \cdot 4-30 \cdot 2$, length of outer mandibular barbel $44 \cdot 2-76 \cdot 3$. Branchiostegal rays 5 (7) or 6 (1). Gill rakers $1+5$ (3). Vertebrae $17+18=35(1), 17+19=36$ (3) or $18+18=36(2)$.

Fin ray counts: dorsal I,4,i (8); pectoral I,6 (1) or I,6,i (7); pelvic i,5 (8); anal ii,5,i (1), ii,6,i (2), iii,4,i (1) or iii, 5,i (4); caudal 6/6 (1), 6/7 (3) or 7/6 (4). Dorsal origin nearer tip of snout than caudal flexure. Pectoral spine stout, without serrations on posterior edge. Caudal fin weakly emarginate.

\section{Colouration}

Dorsal surface of head and body cream to dark yellow, with dark brown spots scattered randomly on dorsal surface of head. Dorsolateral and lateral surfaces of body posterior to dorsal-fin base cream with brown patches of various shades forming a reticulate pattern. Belly, chest and ventral surface of head cream or dark yellow, without spots. Dorsal, pectoral, pelvic and anal fins cream with one or two dark brown bands, one occasionally present at base of the fins and another near edge. Caudal fin cream, with dark brown band near edge and dark brown patch at base of caudal peduncle. Barbels and pectoral spines cream or dark yellow, with dark brown spots sometimes present on dorsal surfaces. Some specimens overall dark brown, with dark brown pectoral fins and brown stripes on other fins as for light-coloured specimens.

\section{Distribution}

Known only from the Kinabatangan and Segama River drainages, and possibly from the Kayan River drainage, in north-eastern Borneo (Fig. 15). 


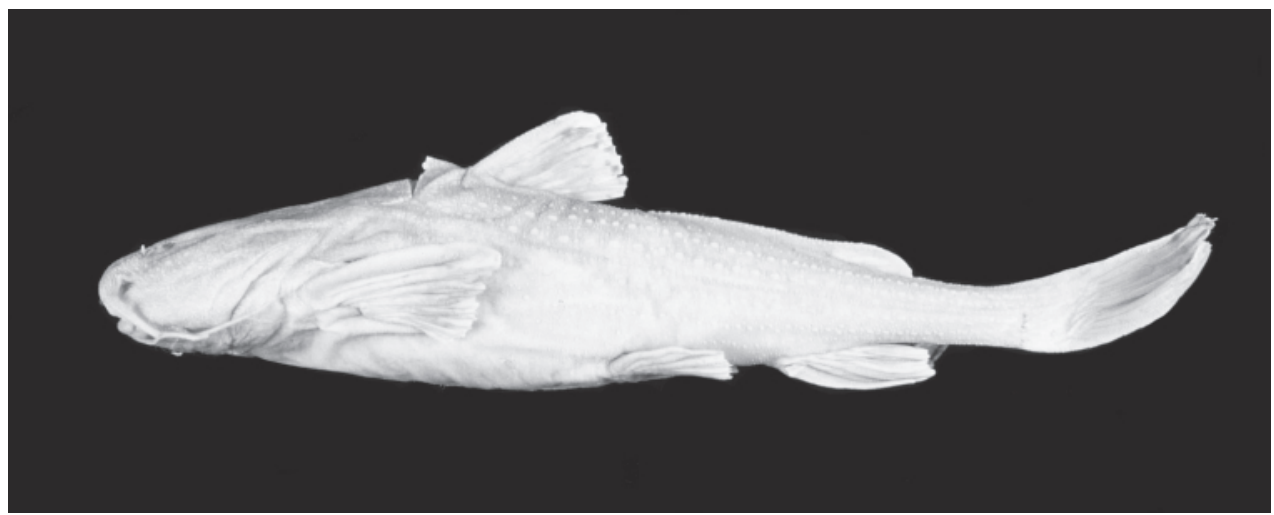

FIG. 17. Acrochordonichthys pachyderma, FMNH 68007, 85.9 mm L $L_{S}$; Borneo: Kinabatangan River drainage.

Etymology

From the Latin falx, meaning scythe and fere, meaning to bear; in allusion to the smooth, recurved pectoral spine of this species.

\section{Remarks}

The lack of serrations in the pectoral spines of $A$. falcifer and A. pachyderma is not a sex-related character, as it is seen in both males and females.

All the specimens of $A$. falcifer were obtained from the edge of a river, which had a sand substrate overlaid with a $15-20 \mathrm{~cm}$ layer of leaf and small woody debris. The water was relatively shallow $(<40 \mathrm{~cm})$ and slow-flowing and most specimens were caught on rising or falling waters following floods.

Rendahl's (1922) record of $A$. pachyderma from Bulungan in the Kayan River drainage may refer to this species, but this specimen could not be found to ascertain its identity.

ACROCHORDONICHTHS PACHYDERMA VAILLANT, 1902 (FIG. 17)

Acrochordonichthys pachyderma Vaillant, 1902: 66, figs 11-13 (type locality: Bloeoe [=Bluu] River, Mahakam basin, Borneo); Popta, 1906: 66; Weber \& de Beaufort, 1913: 370; Inger \& Chin, 1962: 134, fig. 62D; Lim \& Wong, 1994: 55. Acrochordonichthys melanogaster (non Bleeker)—Kottelat, 1994: 414.

Acrochordonichthys cf. melanogaster-Roberts, 1989: 138 (in part); Christensen, 1992: 601.

\section{Material examined}

RMNH 7560, 1 ex., syntype, 144.8 mm $L_{S}$; Borneo: Bo. RMNH 7843, 1 ex., syntype, $105.4 \mathrm{~mm} L_{\mathrm{S}}$; Borneo: Bloeoe. FMNH 68007, 1 ex., $85.9 \mathrm{~mm} L_{\mathrm{S}}$; Borneo: Sabah, East Coast Residency, Kinabatangan District, Deramakot Camp, Kinabatangan River. ZMA 119.419, 1 ex., 94.1 mm $L_{S}$; Borneo: Lebang Hara, Sungai Serawai $\left(0^{\circ} 20^{\prime} \mathrm{S} ; 112^{\circ} 27^{\prime} \mathrm{E}\right)$.

\section{Differential diagnosis}

Acrochordonichthys pachyderma can be differentiated from congeners of the A. rugosus species group in its colouration (overall cream $v$. generally dark 
brown with many irregular patches of light brown) and, except for A. falcifer, lack ( $v$. presence) of serrations on the posterior edge of the pectoral spine.

\section{Description}

Head depressed, broad, body moderately compressed. Dorsal profile rising evenly but not steeply from tip of snout to origin of dorsal fin, then sloping gently ventrally from there to end of caudal peduncle. Ventral profile horizontal to origin of anal fin, then sloping dorsally to end of caudal peduncle. Head covered with small tubercles with poorly demarcated and indistinct margins, body with such tubercles arranged in five or six longitudinal rows on each side. Occipital process narrow, tip tapering, reaching interneural. Premaxillary toothband not exposed when mouth closed. In $\% L_{\mathrm{S}}$ : head length $24 \cdot 3-26 \cdot 1$, head width 24.4-28.1, head depth 15.9-21.4, predorsal distance 37.5-39.2, preanal length $67 \cdot 6-69 \cdot 8$, prepelvic length $50 \cdot 7-55 \cdot 3$, prepectoral length $23 \cdot 8$ $29 \cdot 0$, body depth at anus $12 \cdot 1-17 \cdot 2$, length of caudal peduncle $21 \cdot 1-23 \cdot 6$, depth of caudal peduncle $4 \cdot 8-5 \cdot 6$, pectoral-spine length $17 \cdot 2-18 \cdot 2$, pectoral-fin length $19 \cdot 3-21 \cdot 3$, length of dorsal-fin base $8 \cdot 2-10 \cdot 1$, pelvic-fin length $11 \cdot 2-12 \cdot 9$, length of anal-fin base $8 \cdot 6-10 \cdot 8$, caudal-fin length $16 \cdot 8-20 \cdot 5$, length of adipose-fin base $27 \cdot 2-31 \cdot 7$, dorsal to adipose distance $4 \cdot 8-8 \cdot 4$; in $\% L_{\mathrm{H}}$ : snout length $36 \cdot 1-40 \cdot 2$, interorbital distance $34 \cdot 2-41 \cdot 2$, eye diameter $4 \cdot 2-7 \cdot 4$, length of nasal barbel 6.9-9.0, length of maxillary barbel 55.5-72.2, length of inner mandibular barbel 15.9-21.9, length of outer mandibular barbel 37.3-63.9. Branchiostegal rays 5 (2). Gill rakers $1+4$ (1) or $1+5$ (1). Vertebrae $17+20=37$ (1).

Fin ray counts: dorsal I,4,i (4); pectoral I,6,i (4); pelvic i,5 (4); anal iii,5,i (1) or ii,6,i (3); caudal 6/6 (1) or 7/6 (3). Dorsal origin nearer tip of snout than caudal flexure. Pectoral spine stout, without serrations on posterior edge. Caudal fin weakly emarginate.

\section{Colouration}

Dorsal and ventral surfaces of head and body cream, without any trace of dark spots. Dorsal, pectoral, pelvic and anal fins cream with one or two dark brown bands, one present occasionally at base of fins and another near edge. Caudal fin cream, with dark brown band near edge and dark brown patch at base of caudal peduncle. Barbels and pectoral spines cream or dark yellow, with dark brown spots sometimes present on dorsal surfaces.

\section{Distribution}

Known only from the Kapuas, Mahakam and Kinabatangan River drainages in western, eastern and north-eastern Borneo, respectively (Fig. 15).

ACROCHORDONICHTHYS RUGOSUS (BLEEKER, 1847) (FIG. 18)

Pimelodus rugosus Bleeker, 1847: 11 (type locality: Surakarta, Java); Bleeker, 1850: 10; Bleeker, 1854a: 65; Bleeker, 1857: 477.

Pimelodus melanogaster Bleeker, 1854a: 89 (type locality: confluence of Lamatang and Enim rivers, Palembang province, Sumatra).

Pimelodus pleurostigma Bleeker, 1854b: 442 (type locality: Batavia [= Jakarta], Java).

Pimelodus zonatus Bleeker, 1854b: 444 (type locality: Batavia [=Jakarta], Java). 


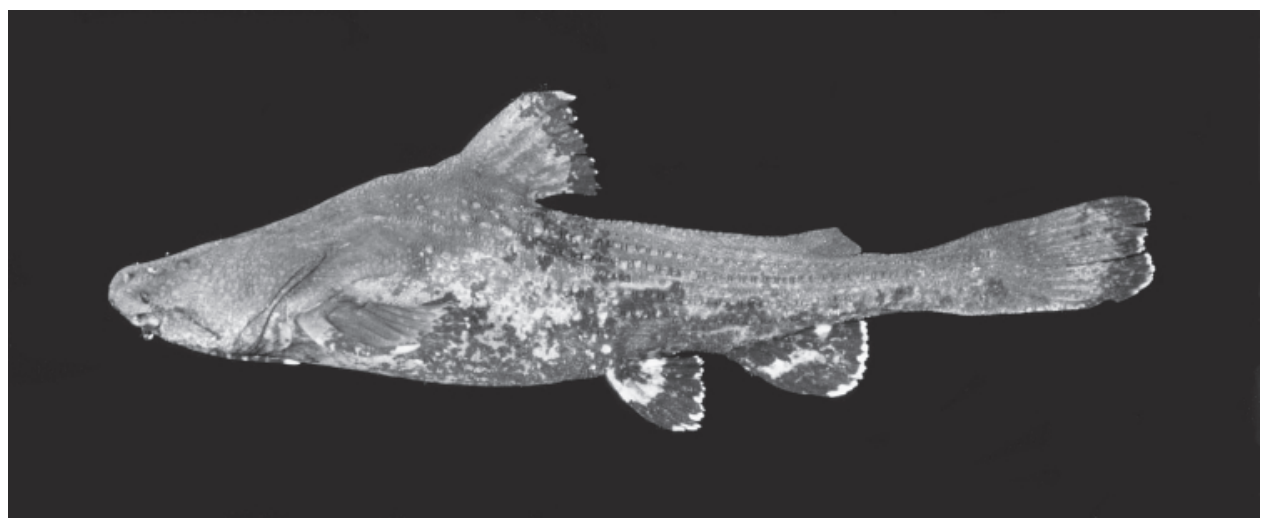

FIG. 18. Acrochordonichthys rugosus, ZRC 39290, $93.6 \mathrm{~mm} L_{\mathrm{S}}$; Thailand: Mae Nam Sungai Kolok drainage.

Acrochordonichthys platycephalus Bleeker, 1858: 224; Bleeker, 1859: 136; Bleeker, 1862: 67, pl. 84, fig. 2; Günther, 1864: 94.

Acrochordonichthys melanogaster-Bleeker, 1858: 225; Bleeker, 1859: 136; Bleeker, 1862: 67, pl. 84, fig. 3; Günther, 1864: 94; Weber \& de Beaufort, 1913: 369; Hora \& Gupta, 1941: 30, fig. 6; Zakaria-Ismail, 1984: 25; Kottelat et al., 1993: 74, pl. 36; Lim et al., 1993: 7; Vidthayanon et al., 1998: 46.

Acrochordonichthys rugosus-Bleeker, 1858: 227; Bleeker, 1859: 136; Bleeker, 1862: 68, pl. 83, fig. 4; Günther, 1864: 95; Weber, 1894: 420; Weber \& de Beaufort, 1913: 368; Hora, 1941: 8, figs 1-2, pl. 1 fig. 4; Hora \& Gupta, 1941: 31; Zakaria-Ismail, 1984: 25; Kottelat et al., 1993: 75, pl. 36; Lim et al., 1993: 7; de Pinna, 1996: 7; Vidthayanon et al., 1998: 46.

Acrochordonichthys zonatus_-Bleeker, 1859: 136; Bleeker, 1862: 69, pl. 84 fig. 5; Günther, 1864: 95.

Acrochordonichthys pleurostigma-Bleeker, 1862: 68, pl. 83 fig. 5; Bleeker, 1859: 136; Günther, 1864: 95; Weber \& de Beaufort, 1913: 368, fig. 149.

Sosia chamaeleon var. pallida Vaillant, 1902: 87, figs 22-24 (type locality: Sintang, Borneo).

Acrochordonichthys obscurus Popta, 1904: 187 (type locality: Bongan River, Kapuas basin, Borneo); Popta, 1906: 55, pl. 3 figs 11a-b; Weber \& de Beaufort, 1913: 370.

Acrochordonichthys Büttikoferi Popta, 1904: 188 (type locality: Bongan River, Kapuas basin, and Bo River, Mahakam basin, Borneo); Popta, 1906: 58, pl. 3 figs $12 \mathrm{a}-\mathrm{b}$.

Acrochordonichthys varius Popta, 1904: 189 (type locality: Bo River, Mahakam basin, Borneo); Popta, 1906: 63, pl. 4 figs 13a-b; Weber \& de Beaufort, 1913: 370.

Acrochordonichthys büttikoferi-Weber \& de Beaufort, 1913: 370.

Acrochordonichthys ischnosoma (non Bleeker, 1858)-Mohsin \& Ambak, 1982: 101, fig. 1; Mohsin \& Ambak, 1983: 122, fig. 89.

Acrochordonichthys cf. melanogaster-Roberts, 1989: 138, fig. 106; Kottelat et al., 1992: 11; Khan et al., 1996: 39; Tan \& Ng, 2000: 288.

Acrochordonichthys cf. rugosus-Ng \& Rachmatika, 1999: 171, Fig. 3(b). 


\section{Material examined}

JavalSumatra: BMNH 1863.12.11.161, 1 ex., syntype ?, $73.6 \mathrm{~mm} L_{\mathrm{S}}$; Bleeker collection. RMNH 6883, 2 ex., syntype(s) ?, 73.5-89.0 $\mathrm{mm} L_{\mathrm{S}}$; Bleeker collection.

Java: RMNH 4188, 1 ex., 79.1 mm $L_{S}$; Bleeker collection (syntype of $A$. pleurostigma). RMNH 6879, 4 ex., 41.3-48.2 mm $L_{\mathrm{S}}$; Bleeker collection (syntypes of $A$. pleurostigma). RMNH 6880, 5 ex., 44.4-64.7 mm $L_{\mathrm{S}}$; Batavia; Bleeker collection (syntypes of $A$. zonatus). ZMA 119.420, 1 ex., $89 \cdot 7 \mathrm{~mm} L_{S}$; ZMA 119.976, 1 ex., 69.3 $\mathrm{mm} L_{\mathrm{S}}$; Buitenzorg.

Sumatra: BMNH 1863.12.11.152, 1 ex., $89.7 \mathrm{~mm} L_{\mathrm{S}}$; Palembang; Bleeker collection (holotype of $A$. platycephalus). BMNH 1863.12.11.160, 1 ex., 94.9 mm $L_{\mathrm{S}}$; ' Provincia Palembang, ubi confluunt flumina Lamatang et Enim '; Bleeker collection (holotype of $A$. melanogaster). RMNH 15972, 1 ex., $99.5 \mathrm{~mm} L_{\mathrm{S}}$; Lampung. ZMA 101.956, 2 ex., 75.0-81·3 $\mathrm{mm} L_{\mathrm{S}}$; highlands of Padang, Batang Si Nama (=Kumanis).

Borneo: RMNH 7848, 1 ex., $68.5 \mathrm{~mm} L_{\mathrm{S}}$; Sintang (lectotype of $S$. chamaeleon var. pallida). RMNH 33551, 1 ex., $68.1 \mathrm{~mm} L_{\mathrm{S}}$; data as for RMNH 7848 (paralectotype of $S$. chamaeleon var. pallida). RMNH 7556, 1 ex., $107.9 \mathrm{~mm} L_{\mathrm{S}}$; Bongan (holotype of $A$. obscurus). RMNH 7557, 1 ex., $124.9 \mathrm{~mm} L_{\mathrm{S}}$; Bongan (syntype of $A$. buettikoferi). RMNH 7558, 2 ex., 85·6-91·1 mm $L_{\mathrm{S}}$; Bo (syntypes of $A$. buettikoferi). RMNH 7559, 2 ex., 94.8-127·1 mm $L_{\mathrm{S}}$; Bo (syntypes of $A$. varius). RMNH 7850, 1 ex., $58.3 \mathrm{~mm} L_{\mathrm{S}}$; Raoen (syntype of $A$. chamaeleon). BMNH 1997.7.17.7, 1 ex., 97.5 mm $L_{S}$; Kalimantan Tengah, Sungai Barito drainage, Desa Kerendan (Sungai Lahei and surrounding habitats). BMNH 1997.7.17.17, 1 ex., 87.7 mm $L_{S}$; Kalimantan Tengah, Sungai Barito drainage, Sungai Idow above a waterfall c. $7 \mathrm{~km}$ upstream from Sungai Kerendan (a tributary of Sungai Lahei). FDS, 1 ex., $104.5 \mathrm{~mm} L_{S}$; Sarawak, Rajang River near Kanowit. MZB 3690, 1 ex., $68.4 \mathrm{~mm} L_{S}$; Kalimantan Barat, Sungai Belantian, $87 \mathrm{~km}$ ENE of Pontianak and $6 \mathrm{~km}$ by road E of Ngabang. MZB 7102, 1 ex., 72.0 mm $L_{S}$; Kalimantan Tengah, Sungai Laung, Desa Maruwei, Laung Tuhup. MZB 9170, 1 ex., 66.2 mm $L_{S}$; Borneo: Kalimantan Barat, Kapuas River drainage, Sungai Peyang, a tributary of Sungai Embaloh. MZB 9424, 1 ex., 102.1 mm $L_{S}$; Kalimantan Barat, Kapuas River drainage, Sungai Sebaya, a tributary of Sungai Embaloh. ZMH 12012, 1 ex., $93.0 \mathrm{~mm} L_{\mathrm{S}}$; Tandjung.

Peninsular Malaysia: CAS 94929, 1 ex., 89.7 mm $L_{\mathrm{S}}$; Kelantan, Sungai Pergau at Belimbing. FMNH 51741, 1 ex., 79.5 mm $L_{\mathrm{S}}$; FMNH 62309, 1 ex., $46 \cdot 3 \mathrm{~mm}$ $L_{\mathrm{S}}$; ZRC 2361, 3 ex., 74·2-87.7 $\mathrm{mm} L_{\mathrm{S}}$; ZRC 2362, 1 ex., $78 \cdot 4 \mathrm{~mm} L_{\mathrm{S}}$; ZRC 2363, 1 ex., 79.2 mm $L_{\mathrm{S}}$; ZRC 2496, 2 ex., 61·3-74.6 mm $L_{\mathrm{S}}$; ZRC 3216, 1 ex., $81 \cdot 5 \mathrm{~mm}$ $L_{\mathrm{S}}$; ZRC 7764, 1 ex., 46.3 mm $L_{\mathrm{S}}$; ZRC 14765, 1 ex., $81.9 \mathrm{~mm} L_{\mathrm{S}}$; Pahang, Kuala Tahan. ZRC 2342, 2 ex., 55·3-66.0 mm $L_{S}$; Perak, Jalong, hill stream 1000-2000 ft. ZRC 5167-5187, 21 ex., 46.2-84.5 mm $L_{S}$; Pahang, Taman Negara, Chaga Sireh, Sungai Tahan. ZRC 7770-7771, 2 ex., 50.2-56.0 mm $L_{S}$; Kelantan, Sungai Sok. ZRC 23413-23415, 3 ex., 64.6-111.0 mm $L_{S}$; ZRC 24514-24517, 4 ex., 56·1-111.0 mm $L_{S}$; CMK 8178, 3 ex., 66.9-78.0 mm $L_{S}$; Terengganu, Sungai Brang, tributary of Sungai Terengganu immediately downriver of Sekayu Waterfall Park. ZRC 27598, 1 ex., 47.6 mm $L_{S}$; Selangor, Sabak Bernam, Sungai Bernam. ZRC 27667, 1 ex., $68.5 \mathrm{~mm} L_{\mathrm{S}}$; Selangor, Sungai Bernam 
headworks. ZRC 38443, 1 ex., $44.5 \mathrm{~mm} L_{\mathrm{S}}$; Selangor, Sungai Bernam headworks.

Thailand: ZRC 39290, 7 ex., 44.7-93.6 mm $L_{\mathrm{S}}$; Narathiwat province, Sungai Kolok. ZRC 43349, 3 ex., 46·0-68·1 mm $L_{\text {S }}$; CMK 12195, 3 ex., 52·2-77·1 mm $L_{\mathrm{S}}$; Narathiwat province, Mae Nam Sungai Kolok at Ban Sac, $7 \mathrm{~km}$ south of Ban Bu Ke Ta (5 47'31" N 101 51'43" E). CMK 12878, 13 ex., 46.7-85.5 mm $L_{\mathrm{S}}$; Narathiwat province, Mae Nam Sai Buri at Sukhirin. NIFI, 3 ex., 64.0-99.0 mm $L_{\mathrm{S}}$; Pattani River at Yala.

\section{Differential diagnosis}

Acrochordonichthys rugosus differs from $A$. chamaeleon in having longer nasal barbels $\left(6 \cdot 5-15 \cdot 6 \% L_{\mathrm{H}} v \cdot 1 \cdot 0-6 \cdot 0\right)$ and a head with steeply-sloping (v. gentlysloping) lateral margins and a convex ( $v$. broadly rounded) snout when viewed dorsally (Fig. 6); from $A$. falcifer in having an adipose fin with an angular ( $v$. rounded) posterior margin (Fig. 5); from A. pachyderma in its colouration (generally dark brown with many irregular patches of light brown $v$. overall cream) and presence ( $v$. lack) of serrations on the posterior edge of the pectoral spine.

\section{Description}

Head depressed, broad, body moderately compressed. Dorsal profile rising evenly but not steeply from tip of snout to origin of dorsal fin, then sloping gently ventrally from there to end of caudal peduncle. Ventral profile horizontal to origin of anal fin, then sloping dorsally to end of caudal peduncle. Head covered with small tubercles with poorly demarcated and indistinct margins, body with such tubercles arranged in five or six longitudinal rows on each side. Occipital process narrow, tip tapering, reaching interneural. Premaxillary toothband not exposed when mouth closed. In $\% L_{\mathrm{S}}$ : head length 20.5-28.3,

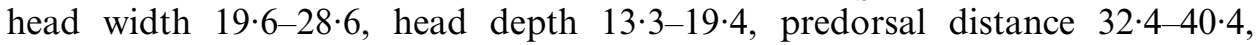
preanal length $66 \cdot 6-74 \cdot 2$, prepelvic length $49 \cdot 6-57 \cdot 8$, prepectoral length $20 \cdot 9$ $28 \cdot 6$, body depth at anus $9 \cdot 6-14 \cdot 3$, length of caudal peduncle $18 \cdot 9-26 \cdot 1$, depth of caudal peduncle $4 \cdot 6-6 \cdot 5$, pectoral-spine length $17 \cdot 5-21 \cdot 1$, pectoral-fin length $19 \cdot 8-26 \cdot 3$, length of dorsal-fin base $7 \cdot 9-10 \cdot 5$, pelvic-fin length $10 \cdot 3-14 \cdot 0$, length of anal-fin base $7 \cdot 4-12 \cdot 7$, caudal-fin length $15 \cdot 7-23 \cdot 2$, length of adipose-fin base

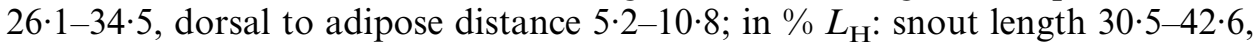
interorbital distance $29 \cdot 8-48 \cdot 5$, eye diameter $4 \cdot 3-8 \cdot 0$, length of nasal barbel $6 \cdot 5-15 \cdot 6$, length of maxillary barbel $51 \cdot 0-83 \cdot 3$, length of inner mandibular barbel

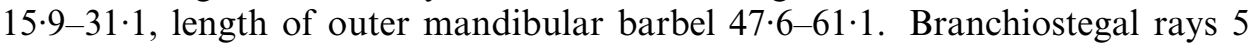
(7) or $6(4)$. Gill rakers $1+3(1), 1+4(5)$ or $1+5(3)$. Vertebrae $18+17=35$ (2), $19+16=35(1), 17+19=36(3), 18+18=36(4), 19+17=36(3), 18+19=37$ (2), $19+18=37$ (9) or $20+17=37$ (2).

Fin ray counts: dorsal I,3,i (1), I,4 (1) or I,4,i (65); pectoral I,5,i (5), I,6 (1), I,6,i (57), I,7 (3) and I,7,i (1); pelvic i,5 (67); anal ii,4,ii (1), iii,4,i (9), iii,4,ii (4), ii,5,i (3), ii,5,ii (1), iii,5 (1), iii,5,i (38), ii,6,i (7), iii,6 (1), and iii,6,i (2); caudal 6/6 (3), $6 / 7$ (1) or $7 / 6$ (63). Dorsal origin nearer tip of snout than caudal flexure. Pectoral spine stout, with 1 (1), 2 (1), 3 (2), 4 (12), 5 (23), 6 (15) or 7 (3) serrations on posterior edge. Caudal fin weakly emarginate. 


\section{Colouration}

Dorsal surface of head and body chestnut brown, sometimes with small dark brown patches scattered randomly on dorsal surface of head. Dorsolateral, lateral and sometimes ventral surfaces of body posterior to dorsal-fin base dark brown, with chestnut brown saddle on dorsolateral surface over adipose fin. In some specimens, saddle is absent and replaced by longitudinal series of chestnut brown spots present, sometimes coalescing to form patches. Belly, chest and ventral surface generally lighter in colour, without spots. Dorsal, pectoral, pelvic and anal fins cream with one or two dark brown bands, one present occasionally at base of fins and another near edge. In some specimens, colour pattern of fins is reversed and fins are overall dark brown with cream bands. Caudal fin cream, with dark brown band near edge and dark brown patch at base of caudal peduncle. Barbels and pectoral spines cream or dark yellow, with dark brown spots sometimes present on dorsal surfaces. Some specimens overall dark brown throughout and lack both spots and saddle.

\section{Distribution}

Known from the Solo, Ciliwung and Citarum River drainages in Java; the Barito, Kapuas, Mahakam and Rajang River drainages in Borneo; the Bernam, Terengganu, Mae Nam Sungai Kolok, and Pattani River drainages in Peninsular Malaysia and southern Thailand; and the Musi and Tulangbawan River drainages in Sumatra (Fig. 15).

\section{Remarks}

After examining the types of the six nominal species described by Bleeker, the one nominal sub-species described by Vaillant, and the four nominal species described by Popta, it is concluded that they are all conspecific. The characters that were used in diagnosing the species (colouration, length of the occipital process and presence of fontanels) show considerable intraspecific variation, as discussed above. No other distinct morphological differences were found among the types.

Bleeker (1847) described Pimelodus rugosus from Surakarta in Java, but gave no indication of the size or number of specimens examined. Later, he obtained at least one more specimen from Palembang in Sumatra (Bleeker, 1854a: 65) again without any indication of size. In his Atlas (Bleeker, 1862), he lists a total of three specimens from both Java and Sumatra, but did not correlate the sizes of the specimens with their collection localities, so there is no way to determine which specimen(s) came from Sumatra. This makes it extremely difficult to determine the holotype (or syntypes) from among the three specimens. As $A$. rugosus appears to be relatively widespread and there is little problem with the identities of this species, it would be desirable, but not necessary to designate a lectotype or even a neotype, especially since fresh specimens could not be obtained from Java.

Vaillant (1902) described the specimens of Sosia chamaeleon from Sintang in the middle part of the Kapuas River drainage as var. pallida, stating that they differed from the other syntypes in having a narrower head and interorbital distance, as well as a different colour pattern. Present examination of the 
syntypes reveal that these specimens, as well as one of the other smaller syntypes of $A$. chamaeleon (RMNH 7850, $58.3 \mathrm{~mm} L_{\mathrm{S}}$ ) are a distinct species and conspecific with the types of the species described by Popta (1904).

Popta (1904) described three species of Acrochordonichthys, using mainly the differences in colour pattern to distinguish them. The colour pattern shows considerable intraspecific variation and the differences observed by Popta fall within the range of colour variation described for $A$. rugosus.

In the north-eastern Malay Peninsula, A. rugosus occurs in clear, swiftly flowing forested streams with a $\mathrm{pH}$ of $7 \cdot 0$ and sandy or rocky bottoms. The fish were hiding under submerged logs or rocks with some leaf litter in the swifter parts of the stream. Alfred (1969) reported that A. rugosus was 'buried in sand under rocks at a water velocity of 2 feet per second and well away from the main channel of the river' in the headwaters of the Pahang River. Acrochordonichthys rugosus is a predatory fish; one specimen obtained from Sungai Brang in Terengganu in Peninsular Malaysia regurgitated three balitorid loaches of the genus Nemacheilus and one sisorid catfish of the genus Glyptothorax. Its general lethargy suggests that it is an ambush predator rather than an active hunter.

The authors thank the following for permission to examine material under their care: D. Siebert, P. Wong, M. A. Rogers, I. Rachmatika, M. de Pinna, M. van Oijen, and H. Wilkens; M. Kottelat for the loan of material and commenting on an earlier version of the manuscript; K. Martin-Smith for obtaining material from Sabah and providing information on their habitat; H. H. Tan for taking the pictures and K. Lim for help with the figures.

\section{References}

Alfred, E. R. (1969). The Malayan cyprinoid fishes of the family Homalopteridae. Zoologische Mededelingen 43, 213-237.

Bertin, L. \& Estève, R. (1950). Catalogue des types de poissons du muséum National d'Histoire Naturelle. 5e partie. Ostariophysaires (Siluriformes). Paris: Imprimerie Nationale.

Bleeker, P. (1847). Nieuwe bijdrage tot de kennis der Siluroiden van Java. Verhandelingen van het Bataviaasch Genootschap van Kunsten en Wetenschappen 21, 1-12.

Bleeker, P. (1850). Bijdrage tot de kennis der ichthyologische fauna van Midden- en Oost-Java, met beschrijving van eenige nieuwe species. Verhandelingen van het Bataviaasch Genootschap van Kunsten en Wetenschappen 23, 1-23.

Bleeker, P. (1854a). Overzigt der ichthyologische fauna van Sumatra met beschrijving van eenige nieuwe soorten. Natuurkundig Tijdschrift voor Nederlandsch Indië 7, 49-108.

Bleeker, P. (1854b). Specierum piscium javanensium novarum vel minus cognitarum diagnoses adumbratae. Natuurkundig Tijdschrift voor Nederlandsch Indië 7, 415-448.

Bleeker, P. (1857). Over eenige vischverzamelingen van verschillende gedeelten van Java. Natuurkundig Tijdschrift voor Nederlandsch Indië 13, 475-480.

Bleeker, P. (1858). De visschen van den Indischen Archipel. Beschreven en toegelicht. Siluri. Acta Societatis Scientiarum Indo-Neèrlandicae 4, i-xii+1-370 (Also published separately as Ichthyologiae Archipelagi Indici Prodromus, Vol. 1 Siluri. Batavia: Lange.)

Bleeker, P. (1859). Enumeratio specierum piscium hucusque in Archipelago indico observatarum, adjectis habitationibus citationibusque, ubi descriptiones 
earum recentiores reperiuntur, nec non speciebus Musei Bleekeriani Bengalensibus Japonicis, Capensibus Tasmanicisque. Acta Societatis Scientiarum Indo-Neèrlandicae 6, 1-276.

Bleeker, P. (1862). Atlas Ichthyologique des Indes Orientales Néêrlandaises. Tome 2. Silurö̈des, Chacoïdes et Hétérobranchoïdes. Amsterdam: Frederic Muller, 112 pp., pls. 49-101.

Christensen, M. S. (1992). Investigations on the ecology and fish fauna of the Mahakam river in east Kalimantan (Borneo), Indonesia. Internationale Revue der Gesamten Hydrobiologie 77, 593-608.

Cracraft, J. (1989). Speciation and its ontology. In Speciation and its Consequences (Otte, D. \& Endler, J., eds), pp. 28-59. Sunderland: Sinauer Associates.

Davies, A. \& Abdullah, A. R. (1989). Freshwater Fish Survey of the North Selangor Peat Swamp Forest. AWB Publication No. 46. Kuala Lumpur: Asian Wetlands Bureau.

Eschmeyer, W. N. (1998). Catalog of Fishes. San Francisco: California Academy of Sciences.

Ferraris, C. (1991). Catfish in the Aquarium. Morris Plains, N.J.: Tetra Press.

Günther, A. (1864). Catalogue of Fishes in the British Museum, Vol. 5. London: Trustees of the British Museum.

Hora, S. L. (1941). On a small collection of fish from Perak, Federated Malay States. Bulletin of the Raffles Museum 17, 5-10.

Hora, S. L. \& Gupta, J. C. (1941). Notes on Malayan fishes in the collection of the Raffles Museum, Singapore. I. Catfishes of the families Siluridae, Bagridae, Amblycepidae, Akysidae, Sisoridae, Chacidae, Schilbeidae and Clariidae. Bulletin of the Raffles Museum 17, 12-43.

Hubbs, C. L. \& Lagler, K. F. (1947). Fishes of the Great Lakes region. Bulletin of the Cranbrook Institute of Science 26, 1-186.

Inger, R. F. \& Chin, P. K. (1962). The freshwater fishes of North Borneo. Fieldiana: Zoology 45, 1-268.

International Commission for Zoological Nomenclature. (1999). International Code of Zoological Nomenclature, 4th edn. London: International Trust for Zoological Nomenclature.

Khan, M. S., Lee, P. K. Y., Cramphorn, J. \& Zakaria-Ismail, M. (1996). Freshwater Fishes of the Pahang River basin, Malaysia. Wetlands International-Asia Pacific Publication No. 112. Kuala Lumpur: Wetlands International-Asia Pacific.

Kottelat, M. (1994). The fishes of the Mahakam River, east Borneo: an example of the limitations of zoogeographic analyses and the need for extensive fish surveys in Indonesia. Tropical Biodiversity 2, 401-426.

Kottelat, M. (1995). Systematic studies and biodiversity: the need for a pragmatic approach. Journal of Natural History 29, 565-569.

Kottelat, M., Ng, P. K. L. \& Lim, K. K. P. (1992). Recent collections of freshwater fish from Terengganu, Peninsular Malaysia. Malayan Naturalist 46, 7-12.

Kottelat, M., Whitten, A. J., Kartikasari, S. N. \& Wirjoatmodjo, S. (1993). Freshwater Fishes of Western Indonesia and Sulawesi. Hong Kong: Periplus Editions.

Lim, K. K. P. \& Wong, A. (1994). Fishes of the Kinabatangan basin, Sandakan District, Sabah, East Malaysia. Sabah Museum Journal 1, 39-71.

Lim, K. K. P., Ng, P. K. L., Kottelat, M. \& Zakaria-Ismail, M. (1993). A preliminary working list of native freshwater fishes of Peninsular Malaysia. AWB Publication No. 94. Kuala Lumpur: Asian Wetlands Bureau.

Martin-Smith, K. \& Tan, H. H. (1998). Diversity of freshwater fishes from eastern Sabah: annotated checklist for Danum Valley and a consideration of inter- and intra-catchment variability. The Raffles Bulletin of Zoology 46, 573-604.

Mohsin, A. K. M. \& Ambak, M. A. (1982). Freshwater siluroid fishes of Selangor. Malayan Nature Journal 36, 99-112.

Mohsin, A. K. M. \& Ambak, M. A. (1983). Freshwater Fishes of Peninsular Malaysia. Kuala Lumpur: Penerbit Universiti Pertanian Malaysia.

Ng, H. H. (1996). Akysis heterurus, a new species of catfish (Teleostei: Akysidae) from eastern Sumatra. The Raffles Bulletin of Zoology 44, 3-10. 
Ng, H. H. \& Kottelat, M. (1996). Akysis fuscus, a new species of catfish (Teleostei: Akysidae) from the Kapuas basin, Borneo. Ichthyological Exploration of Freshwaters 7, 19-26.

Ng, H. H. \& Kottelat, M. (1998). The catfish genus Akysis Bleeker (Teleostei: Akysidae) in Indochina, with descriptions of six new species. Journal of Natural History 32, $1057-1097$.

Ng, H. H. \& Lim, K. K. P. (1995). A revision of the Southeast Asian catfish genus Parakysis (Teleostei: Akysidae), with descriptions of two new species. Ichthyological Exploration of Freshwaters 6, 255-266.

Ng, H. H. \& Rachmatika, I. (1999). The catfishes (Teleostei: Siluriformes) of Bentuang Karimun National Park, West Kalimantan, Indonesia. The Raffles Bulletin of Zoology 47, 167-183.

Ng, H. H. \& Siebert, D. J. (1998). A revision of the akysid catfish genus Breitensteinia Steindachner (Teleostei: Siluriformes) with descriptions of two new species. Journal of Fish Biology 53, 645-657.

Ng, P. K. L., Tay, J. B., Lim, K. K. P. \& Yang, C. M. (1992). The conservation of the fish and other aquatic fauna of the North Selangor Peat Swamp Forest and adjacent areas. AWB Publication No. 81. Kuala Lumpur: Asian Wetlands Bureau.

de Pinna, M. C. C. (1996). A phylogenetic analysis of the Asian catfish families Sisoridae, Akysidae, and Amblycipitidae, with a hypothesis on the relationships of the Neotropical Aspredinidae (Teleostei, Ostariophysi). Fieldiana: Zoology (New Series) 84, 1-83.

Popta, C. M. L. (1904). Descriptions préliminaires des nouvelles espèces de poissons recueillies au Bornéo Central par M. le Dr. A. W. Nieuwenhuis en 1898 et en 1900. Notes from the Leyden Museum 24, 179-202.

Popta, C. M. L. (1906). Résultats ichthyologiques des voyages scientifique de Monsieur le Professeur Dr. A. W. Nieuwenhuis dans le centre de Bornéo (1898 et 1900). Notes from the Leyden Museum 27, 1-304.

Rendahl, H. (1922). Fische, gesammelt von Herrn Carl Lumholtz in Bulungan, Nordost-Borneo. Nyt Magazin for Naturvidenskaberne 60, 199-204.

Roberts, T. R. (1989). The freshwater fishes of Western Borneo (Kalimantan Barat, Indonesia). Memoirs of the California Academy of Sciences 14, 1-210.

Roberts, T. R. (1992). Revision of the striped catfishes of Thailand misidentified as Mystus vittatus, with descriptions of two new species (Pisces: Bagridae). Ichthyological Exploration of Freshwaters 3, 77-88.

Roberts, T. R. (1994). Systematic revision of Asian bagrid catfishes of the genus Mystus sensu stricto, with a new species from Thailand and Cambodia. Ichthyological Exploration of Freshwaters 5, 241-256.

Tan, H. H. \& Ng, H. H. (2000). The catfishes (Teleostei: Siluriformes) of central Sumatra. Journal of Natural History 34, 267-303.

Vaillant, L. (1902). Résultats zoologiques de l'expédition scientifique Néerlandaise au Bornéo Central. Notes from the Leyden Museum 24, 1-166.

Vidthayanon, C., Karnasuta, J. \& Nabhitabhata, J. (1998). Diversity of Freshwater Fishes in Thailand. Bangkok: Office of Environmental Policy and Planning.

Weber, M. (1894). Die Süsswasser-fische des Indischen Archipels, nebst Bemerkungen über den Ursprung der Fauna von Celebes. In Zoologische Ergebnisse einer Reise in Niederländisch Ost-Indien, Band 3 (Weber, M., ed.), pp. 405-476. Leiden: E. J. Brill.

Weber, M. \& de Beaufort, L. F. (1913). The Fishes of the Indo-Australian Archipelago, Vol. 2. Malacopterygii, Myctophoidea, Ostariophysi: I. Siluroidea. Leiden: E. J. Brill.

Wiley, E. O. (1981). Phylogenetics: the Theory and Practice of Phylogenetic Systematics. New York: John Wiley.

Zakaria-Ismail, M. (1984). Checklist of fishes of Taman Negara. Malayan Naturalist 37, $21-26$. 